\title{
Josip Buturac i njegov svijet
}

\author{
Vjekoslavu Mariću u znak poštovanja i zahvalnosti
}

\begin{abstract}
U radu se problematizira život i djelovanje svećenika, publicista, povjesničara i arhivista Josipa Buturca. Cilj je ovoga članka, uz kritički prikaz Buturčeva života i rada, analizirati njegov odnos prema nekim od temeljnih političkih ideja 19. i 20. stoljeća, vrednovanje djelovanja vodećih ličnosti moderne i suvremene hrvatske povijesti, nacionalni i vjerski identitet te povezanost sa zavičajem. Da bi slika o Josipu Buturcu i njegovu svijetu bila jasnija, u članku se istražuje njegov odnos prema Srbima, četnicima, partizanima i ustašama te razmišljanja o vlastitim moralnim, intelektualnim te duhovnim nastojanjima i dilemama. Bio je čovjek konzervativnog svjetonazora, nesklon komunizmu i liberalizmu. U njegovu životu prožimaju se hrvatski nacionalizam i kršćanski humanizam, isključivost i tolerancija, dijalog i sukob, ali, barem kada je riječ o njegovu djelovanju u razdoblju socijalizma, i visoki adaptivni kapaciteti. To pokazuje uglavnom uspješna integracija u jugoslavenskom socijalističkom sustavu. Ideološke predrasude i emocije ponekad su ga navodile na konstruiranje iskrivljenih slika prošlosti. Svojim pisanim djelima dao je značajan doprinos poznavanju povijesti Katoličke Crkve u Hrvatskoj te razvoju arhivistike.
\end{abstract}

\section{Uvod}

Teško je zamisliti razgovor ili napis koji se odnosi na hrvatsku arhivistiku, historiografiju Požeške kotline i Crkve u Hrvatskoj, a da se pri tome ne spomene Josip Buturac, svećenik i povjesničar, koji je u značajnoj mjeri obilježio područje svoga rada. Temeljni je cilj ovoga članka kritički prikazati životni put i djelovanje Josipa Buturca, s posebnim naglaskom na njegovu povezanost sa zavičajem, izložiti jedan od mogućih odgovora na pitanje u kojoj je mjeri pripadnost zavičaju odredila njegov budući znanstvenoistraživački i publicistički rad. Je li njegov vjerski i nacionalni identitet utjecao na vrednovanje problema kojima se bavio te kakav je bio njegov odnos prema nekim političkim idejama 19. i 20. stoljeća u okvirima konzervativizma, liberalizma i komunizma? Problematizira se njegov odnos prema ustaškom režimu, četnicima i partizanskom pokretu. U čemu se sastoji njegovo vrednovanje vodećih ličnosti moderne i suvremene hrvatske povijesti poput Ante Starčevića, Stjepana Radića, jugoslavenskog kralja Aleksandra I. Karađorđevića, Ante Pavelića, Alojzija Stepinca i Josipa Broza Tita? Kakav je Buturčev odnos prema Srbima? Koji su glavni aspekti njegovih duhovnih, moralnih, ali i intelektualnih težnji? Analize navedenih 
problema i odgovori na postavljena pitanja u nizu su segmenata izvorni doprinos poznavanju života i djelovanja Josipa Buturca. Ovaj pisani rad nije i ne može biti konačna riječ o kompleksnom te višeslojnom životu i radu Josipa Buturca, nego samo jedna u nizu kockica njegova složenoga životnog mozaika. Josip Buturac bio je dijete svoga vremena te ga kao čovjeka, svećenika i povjesničara treba promatrati u okviru vremenskog konteksta u kojem je živio i stvarao svoja pisana djela.

Tijekom istraživanja problemâ koje sam analizirao u ovom radu ponajviše sam se oslanjao na rukopise autobiografskih radova Josipa Buturca iz njegova Osobnoga fonda u Državnom arhivu u Slavonskom Brodu - Odjelu u Požegi (Moja zapamćenja, Lovrečina Grad 1983. i Zabilježbe - autobiografija Josipa Buturca po sjećanju i savjesti, a radi se o rukom pisanim autobiografskim zapisima, zatim Moja zapamćenja, rukopis pisan pisaćim strojem u tri dijela). U Osobnom fondu Josipa Buturca pohranjeni su i njegovi dokumenti (izvodi iz matica, domovnica, putovnice, indeksi, dekreti te drugi dokumenti), rukopisi zbirkâ pjesama i objavljenih članaka, tekstovi propovjedi i predavanja, korespondencija, novinski članci koji se odnose na njegov život i rad, fotografije i drugo. Što se tiče objavljenih djela o životu i radu Josipa Buturca, potrebno je istaknuti njegovu knjigu Znaci vremena (1994.) u kojoj je u poglavlju „Opis moga života i rada“ prikazao svoj životni put i djelovanje. Značajan prikaz njegova života izložio je Lojzo Buturac u svojoj knjizi Život i djelo dr. Josipa Buturca (2002.). Naveo je podatke uglavnom bez kritičkih komentara i analiza. U prvom dijelu knjige autor je prikazao Buturčev život i stvaralaštvo, a u drugom je objavio njegovu bibliografiju, zatim slijedi popis tekstova drugih autora o radovima Josipa Buturca te o njegovu životu, popis nekrologa povodom njegove smrti, potom kazala samostalnih djela, rasprava i članaka u periodici. U posljednjem dijelu knjige autor je objavio podatke o depozitu Josipa Buturca. Kraći pregled života i bibliografiju Josipa Buturca objavio je Ivan Damiš pod naslovima Dr. Josip Buturac, arhivist i povjesničar. Biobibliografski podaci uz 80. rođendan i Bibliografija dr. Josipa Buturca u vremenskom razdoblju od 1984.-1993. Navedeni radovi tiskani su 1995. godine u knjizi Ulomci za povijest Katoličke crkve u Hrvata, zatim u časopisu Zlatna dolina. Ivica Miškulin objavio je pisani rad „Čaglićka epizoda - prilog životopisu Josipa Buturca“ (2010.), a Daniel Patafta „Historiografska i arhivistička ostavština Josipa Buturca“ (2017.). Radovi dvojice autora objavljeni su u časopisu Instituta za crkvenu povijest Katoličkog bogoslovnog fakulteta Sveučilišta u Zagrebu Croatica Christiana Periodica.

U sagledavanju života i rada Josipa Buturca važan je i njegov razgovor s Arisom Angelisom objavljen u knjizi Ljudi XX stoljeća (2011.). Angelisu je govorio o svome djetinjstvu, svećeničkom pozivu, školovanju, mješovitim brakovima u Kraljevini Jugoslaviji, odnosima Kraljevine Jugoslavije i Vatikana, vjerovanju, odnosu Crkve i masona, politici osmanskih vlasti prema kršćanima, potom o svojoj 
arhivističkoj djelatnosti, o Alojziju Stepincu i drugim povijesnim ličnostima poput Ante Starčevića, Stjepana Radića, Ante Pavelića i Josipa Broza Tita te o braku i celibatu. Opisujući iste situacije iz svoga života te iznoseći vlastita razmišljanja o pojedinim povijesnim ličnostima u nekoliko navedenih neobjavljenih i objavljenih djela, Josip Buturac bio je, uz manja odstupanja, uglavnom dosljedan, ali proširivanjem istraživanja utvrđene su i promjene u njegovim stavovima, posebno o ustaškom režimu i Anti Paveliću. Budući da većina izvora potječe iz Buturčeva pera, bio sam svjestan da nedovoljna kritičnost lako može dovesti do iskrivljenih slika analiziranih problema. Ostale izvore i literaturu kojom sam se koristio naveo sam u bilješkama te u popisu izvora i literature.

Buturčeva autobiografska djela i drugi (ne)objavljeni zapisi vrijedni su izvori za istraživače suvremene crkvene povijesti. Zahvaljujući neposrednim kontaktima s vodećim crkvenim ličnostima u Hrvatskoj, Buturac je imao izravan uvid u složene crkvene prilike. Smatram da su njegovi autobiografski zapisi značajni i kada je riječ o djelovanju zagrebačkog nadbiskupa Alojzija Stepinca jer su dvojica crkvenih dostojanstvenika godinama bila u neposrednom, gotovo prijateljskom odnosu.

\section{Djetinjstvo u Zlatnoj dolini i prvi intelektualni interesi}

Josip Buturac rođen je 14. studenoga 1905. godine u Grabarju, nedaleko od Požege. ${ }^{1}$ Preci njegova oca Antuna doselili su se iz ličkog naselja Podastrane, Župe svetoga Jakova sa sjedištem u Donjem Pazarištu, u Djedinu Rijeku 1780. godine. ${ }^{2}$ Nakon dolaska u novi zavičaj promijenili su ,prezime iz Butorac u Buturac“. ${ }^{3}$ Antun Buturac bio je kovač. ${ }^{4}$ Josipova majka Franjika, rođena Svoboda, bila je moravskoga podrijetla, a djed i baka s majčine strane doselili su se iz Moravske u Slavoniju

1 HR-DASB-PŽ-290, Osobni fond Josipa Buturca 1921. - 1995., kutija 1., Osobni dokumenti, Izvod iz matične knjige rođenih, broj 1/416-1985., Pleternica, 19. 2. 1985.; Hrvatski biografski leksikon, sv. 2: Bj-C, s. v. „Buturac, Josip“, 541-542; Hrvatski leksikon, sv. I: A - K, s. v. „Buturac, Josip“, 176; Hrvatska enciklopedija, sv. 2: Be - Da, s. v. „Buturac, Josip“, 425; Opća enciklopedija Jugoslavenskog leksikografskog zavoda, sv. 1: A - Bzu, s. v. „Buturac, Josip“, 745; Požeški leksikon, s. v. „Buturac, Josip“, 40; Tko je tko u Hrvatskoj - Who is who in Croatia, s. v. „Buturac, Josip“, 100; J. BUTURAC 1981: 125; ISTI 1982: 184; ISTI 1990a: 320; ISTI 1990b: 104. Podaci o datumu, godini i mjestu rođenja navedeni su u gotovo svim napisima o životu i radu Josipa Buturca pa ovdje nije potrebno dalje nizati bibliografske jedinice u kojima su navedeni ovi podaci.

2 Sinteza: ANGELIS 2011: 92; J. BUTURAC 1994: 189; L. BUTURAC 1998: 374; ISTI 2002: 8. O prošlosti obitelji Buturac detaljnije u J. BUTURAC 1980: 23-27.

3 L. BUTURAC 2002: 9.

4 HR-DASB-PŽ-290, Osobni fond Josipa Buturca 1921. - 1995., kutija 2., Autobiografski materijal, Josip Buturac, Moja zapamćenja (rukopis), Lovrečina Grad, 1983., 7; Isto, Josip Buturac, Zabilježbe - autobiografija Josipa Buturca po sjećanju i savjesti (rukopis), 5; ANGELIS 2011: 92; L. BUTURAC 1998: 375; ISTI 2002: 9. 
oko 1890. godine. ${ }^{5}$ Majka Josipa Buturca završila je u Moravskoj sedam razreda osnovne škole. ${ }^{6} \mathrm{U}$ novoj sredini bila je, s obzirom na stupanj obrazovanja, jedna od obrazovanijih osoba. Naime, prema popisu stanovništva provedenom 1931. godine, na području požeškoga kotara živjelo je 52920 stanovnika, od kojih je nepismenih bilo $12344 .^{7}$ S obzirom na broj pismenih, odnosno nepismenih osoba, situacija je mogla biti samo još lošija u vrijeme Josipova djetinjstva. On se ponosio svojim ličkim podrijetlom, a Arisu Angelisu rekao je : „,...moj temperament je lički, ja, a i moja rodbina pomalo preziremo Slavonce zbog njihove lijenosti, nemarnosti i nehaja“. Nije se prvi put umjesto argumentima koristio predrasudama. U istom razgovoru istaknuo je da su njegovi djedovi bili seoski knezovi gotovo dva stoljeća. ${ }^{8}$ Lojzo Buturac napisao je da su Buturci „imali najveću kuću u selu, jedinu sagrađenu od kamena, vlastiti mlin žličar..." te da su „prvi iz sela učili zanate i polazili na daljnje školovanje“. ${ }^{9}$ Po svemu sudeći, dječak Josip rođen je u obitelji koja mu je mogla osigurati odvajanje od seoskog okruženja u kojem je odrastao. ${ }^{10}$

Kada je imao godinu dana, Josip i njegovi roditelji preselili su se u Djedinu Rijeku i živjeli u roditeljskoj kući Josipova oca Antuna Buturca. ${ }^{11}$ Četiri razreda osnovne škole završio je u Ruševu. ${ }^{12}$ Još kao dijete odlazio je k najstarijem čovjeku u selu da mu pripovijeda o starinama. Godine 1914. objavljena je knjiga Julija Kempfa Iz Požeške kotline. Zemljopisne i povijesne crtice za mladež koju je Josip još kao dječak pročitao nekoliko puta. ${ }^{13}$ Čitajući navedenu knjigu, prema vlastitom

5 Sinteza: HR-DASB-PŽ-290, Osobni fond Josipa Buturca 1921. - 1995., kutija 2., Autobiografski materijal, Josip Buturac, Moja zapamćenja (rukopis), Lovrečina Grad, 1983., 10; Isto, Josip Buturac, Zabilježbe - autobiografija Josipa Buturca po sjećanju i savjesti (rukopis), 6; L. BUTURAC 1998: 375; ISTI 2002: 9.

6 HR-DASB-PŽ-290, Osobni fond Josipa Buturca 1921. - 1995., kutija 2., Autobiografski materijal, Josip Buturac, Moja zapamćenja (rukopis), Lovrečina Grad, 1983., 10; Isto, Josip Buturac, Zabilježbe - autobiografija Josipa Buturca po sjećanju i savjesti (rukopis), 6; L. BUTURAC 2002: 9.

7 PAVLICA 1979: 222-223.

8 ANGELIS 2011: 92.

9 L. BUTURAC 1998: 375.

10 O ranom djetinjstvu Josipa Buturca detaljnije u HR-DASB-PŽ-290, Osobni fond Josipa Buturca 1921. - 1995., kutija 2., Autobiografski materijal, Josip Buturac, Moja zapamćenja (rukopis), Lovrečina Grad, 1983., 3-23; Isto, Josip Buturac, Zabilježbe - autobiografija Josipa Buturca po sjećanju i savjesti (rukopis), 5-16; J. BUTURAC 1994: 189-194.

11 J. BUTURAC 1994: 190; L. BUTURAC 2002: 9; DAMIŠ 1995: 293.

12 AFSP, Ostavština Josipa Buturca, Isprave dr. Josipa Buturca I., Svjedodžba polaznica, Niža pučka škola u Ruševu, 30. 6. 1917., broj 8/932; J. BUTURAC 1994: 192-194; L. BUTURAC 2002: 10; DAMIŠ 1995: 293.

13 Sinteza: HR-DASB-PŽ-290, Osobni fond Josipa Buturca 1921. - 1995., kutija 2., Autobiografski materijal, Josip Buturac, Moja zapamćenja (rukopis), Lovrečina Grad, 1983., 18; Isto, Josip Buturac, Zabilježbe - autobiografija Josipa Buturca po sjećanju i savjesti (rukopis), 15; L. BUTURAC 2002: 10; DAMIŠ 1995: 293-294. 
priznanju, donekle je „usvojio Kempfov način pripovijedanja“. ${ }^{14}$ Školsku čitanku pročitao je više puta za nekoliko dana. Čitao je pripovijetke za mlade, kalendare i vjerske publikacije. Radije je ,čitao pouku negoli dječje basne, ako je ta pouka pisana pučkim jezikom“ ${ }^{15}{ }^{1} \mathrm{U}$ svojim Zabilježbama, između ostaloga, zapisao je: „Osobito sam rado učio zemljopis i povijest, a velike povijesne narodne i Kačićeve pjesme nakon 2-3 čitanja znao sam od riječi do riječi." ${ }^{\text {"16 }}$ Sudeći prema ovome, Josip Buturac je od djetinjstva bio orijentiran na prošlost i pisanu riječ.

U ranom djetinjstvu Buturac je asimilirao vrijednosti koje su ga pratile cijelog života. Baka Ana mu je govorila: „Sinko pošao si u školu! Budi marljiv i poslušan. Ustraj do kraja da nam budeš na diku i ponos, a ne na sramotu. Ako odustaneš od škole, sva će se sela sprdati s tobom i s nama, kako smo nešto htjeli, a nismo uspjeli. Svijet je podrugljiv, zavidan i zloban. Radi se ne rukom nego glavom!"“17 Dječak je, suvremenim rječnikom rečeno, bio projekt obitelji i svojim obrazovanjem morao je osigurati prestiž obitelji u lokalnoj sredini koja nije imala milosti prema gubitnicima u životnoj utrci. Taj teret Josip Butorac prihvatio je strpljivo, odgovorno i ustrajno. Sklonost prema obrazovanju, marljivost i odgovornost te poticaj, ali ujedno i pritisak obitelji, u konačnici su ga doveli do uspjeha. Dužnost prema obitelji i odgovornost temeljne su vrijednosti koje je Josip Buturac ponio iz obiteljskog doma. ${ }^{18} \mathrm{O}$ tome je zapisao: „U ljetu sam morao pomagati roditeljima u svim poslovima: na livadi, u polju, okolo kuće, čuvati svinje i krave. Bilo mi je to teško, pa sam to činio nerado, prikriveno ili otvoreno. Stariji su me zbog toga često korili. Željeli su mi utuviti u glavu svijest o dužnosti i odgovornosti; kako je potrebno osposobiti se za život; kako moram zaslužiti kruh svakidašnji i biti od koristi kući i obitelji." ${ }^{19}$

U Požegi upisao je gimnaziju 1917. godine i završio tri razreda, a četvrti u Travniku. Više razrede gimnazije pohađao je u Nadbiskupskoj gimnaziji u Zagrebu. Maturirao je 1925. godine. Bio je prosječan učenik. ${ }^{20}$ Pisao je o svojim

14 HR-DASB-PŽ-290, Osobni fond Josipa Buturca 1921. - 1995., kutija 2., Autobiografski materijal, Josip Buturac, Moja zapamćenja (rukopis), Lovrečina Grad, 1983., 18.

15 Isto, Josip Buturac, Zabilježbe - autobiografija Josipa Buturca po sjećanju i savjesti (rukopis), 15.

16 Isto, 14.

17 Isto, Josip Buturac, Moja zapamćenja (rukopis), Lovrečina Grad, 1983., 4.

18 Isto, Josip Buturac, Zabilježbe - autobiografija Josipa Buturca po sjećanju i savjesti (rukopis), 15.

19 Isto.

20 Sinteza: AFSP, Ostavština Josipa Buturca, Isprave dr. Josipa Buturca I., gimnazijske svjedodžbe i izvještaji, Svjedočanstvo o višem tečajnom ispitu/ispitu zrelosti 25. 6. 1925. (prijepis); HRDASB-PŽ-290, Osobni fond Josipa Buturca 1921. - 1995., kutija 2., Autobiografski materijal, Josip Buturac, Moja zapamćenja (rukopis), Lovrečina Grad, 1983., 24-33; Isto, Josip Buturac, Zabilježbe - autobiografija Josipa Buturca po sjećanju i savjesti (rukopis), 17-28; J. BUTURAC 1994: 194-196; L. BUTURAC 2002: 10; DAMIŠ 1995: 294; PATAFTA 2017: 160. 
problemima tijekom školovanja. Imao je poteškoća u svladavanju latinskog, grčkog i njemačkog jezika te matematike. $U$ autobiografskim zapisima preispitivao je uzroke vlastitih neuspjeha: „Nesposobnost, nemarnost, bavljenje izvanškolskim poslovima, nespretnost ili slaba sreća? Prijatelji su upozoravali, da bih radi ugleda i časti morao bolje napredovati u školi. Je li meni stalo do ugleda i časti? Ne znam. Istina je da sam drugima izrađivao domaće zadaće koje su bolje ocijenjene od moje i da sam druge poučavao koji su bolje ocijenjeni od mene. Možda je bilo potrebno to poniženje, da se ne uzoholim zbog uspjeha s pjesmicama u časopisima..." ${ }^{\text {21 }}$ Uvjerenje da mu drugi čine nepravdu, pa čak i osjećaj ugroženosti, utemeljeno ili neopravdano, pratili su ga gotovo cijeli život i jasno su vidljivi u autobiografskim zapisima. ${ }^{22}$

Tijekom gimnazijskog školovanja Josip Buturac pisao je pjesme, a neke je i objavio. Tijekom 1921. i 1922. godine svoje pjesme svrstao je u rukopisne zbirke Travanjčice, Karanfilke i Diljogorke. Treba spomenuti i malu bilježnicu naslovljenu Pjesma u kojoj je zapisao pjesme Noć i Radoznalom Emilu Urbanu. Zbirkom Slavujice pokušao je napraviti izbor svojih pjesama i dodao oko trideset novih pjesničkih ostvarenja. Poslije je napravio izbor pjesama za još dvije pjesničke zbirke. Buturac je mnogo godina kasnije - točnije, 1987. - istaknuo da su hrvatski i srpski pisci 19. i 20. stoljeća pjesnički utjecali na njega. Svoje prve pjesme objavio je u časopisu Anđeo čuvar 1919. godine pod naslovom Rano proljeće i Molitva. Njegove crtice, pjesme i pripovijesti izašle su, osim u spomenutom časopisu Anđeo čuvar, i u listovima Krijes, Luč, Travničko smilje, Zumbuli te u časopisu Hrvatska prosvjeta. ${ }^{23}$

U Buturčevim pjesmama prisutni su motivi godišnjih doba (Rano proljeće, Proljeće, Ljetno sunce, Kasna jesen, Zima...), krajolika (Pada lišće, Zelen...) i zavičaja (U Požegi, Prijateljima iz Požege, Opet u Požegi...), a značajno mjesto zauzimaju pjesme emocionalnog (Tužno ferje, Utjeha, Moja tuga...) te duhovnog i vjerskog karaktera (Molitva, Molitva Majci Božjoj, Anđeo čuvar, Križ, Božić...). ${ }^{24}$ Buturac se u mladosti zanosio i idejom slavenske uzajamnosti, a o tome svjedoči

21 HR-DASB-PŽ-290, Osobni fond Josipa Buturca 1921. - 1995., kutija 2., Autobiografski materijal, Josip Buturac, Moja zapamćenja (rukopis), Lovrečina Grad, 1983., 31.

22 Isto, 39, 56, 78, 83, 119-120, 123, 127-132; Isto, Josip Buturac, Zabilježbe - autobiografija Josipa Buturca po sjećanju i savjesti, 230-231; J. BUTURAC 1994: 204-205.

23 Sinteza: HR-DASB-PŽ-290, Osobni fond Josipa Buturca 1921. - 1995., kutija 2., Autobiografski materijal, zbirke pjesama (rukopisi): Travanjčice, 1921., Karanfilke, 1921., Diljogorke, 1922., Slavujice, 1922. - 1925., Pjesme, 1919. - 1925., Pjesme, 1925. te malena bilježnica naslovljena Pjesma, 1922. L. BUTURAC 2002: 12-13; DAMIŠ 1995: 294; NOSIĆ 1998: 379-380; PATAFTA 2017: 160. Lojzo Buturac spomenuo je još jednu zbirku pjesama Josipa Buturca pod naslovom Biserje (L. BUTURAC 2002: 1). Tijekom istraživanja nisam naišao na tu zbirku pjesama.

24 HR-DASB-PŽ-290, Osobni fond Josipa Buturca 1921. - 1995., kutija 2., Autobiografski materijal, zbirke pjesama (rukopisi): Travanjčice, 1921., Karanfilke, 1921., Diljogorke, 1922., Slavujice, 1922. - 1925., Pjesme, 1919. - 1925., Pjesme, 1925. 
i njegova pjesma Slavenima napisana 1919. godine. ${ }^{25}$ Pjesme je pisao kao gimnazijalac, a u jednom od svojih zapisa priznaje: „Ono što je osobno moje, orginalno, izraženo je nejasno, maglovito, jer se nisam usudio jasno i javno izraziti ono što sam osjećao u svom srcu. To je bila borba između dva magneta, trebalo se odlučiti za duhovno ili svjetovno zvanje. ${ }^{26} \mathrm{U}$ istom tekstu ističe da je od djetinjstva imao sklonost prema duhovnom pozivu te da je volio crkve i duhovne knjige, ali se „plašio osamljenosti u duhovnom zvanju. “27 Ipak se odlučio za svećenički poziv i prestao pisati pjesme.

\section{Student i svećenik}

Josip Buturac bio je student Bogoslovskog fakulteta u Zagrebu od 1925. do završetka studija 1929. godine. Poznati crkveni povjesničar i profesor Bogoslovskog fakulteta Julije Jelenić razvio je u Josipa ljubav prema crkvenoj povijesti koja ga nije napustila do smrti. Kao student, pod mentorstvom Julija Jelenića, napisao je tri seminarska rada. Jedan od spomenutih triju seminarskih radova objavljen je kao samostalno djelo 1927. pod naslovom Ruševo i okolica u prošlosti. Za ta tri seminarska rada dobio je Kraljevsku svetosavsku nagradu. Još je kao student Buturac mnogo vremena provodio u arhivima, a posebno u Nadbiskupskome arhivu, proučavajući dokumente na temelju kojih je stvarao svoja prva historiografska djela. Njegovu posebnu sklonost, a sudeći prema opsegu pisane ostavštine, možemo slobodno reći i strast prema izučavanju povijesti, uočio je tadašnji zagrebački nadbiskup Antun Bauer koji ga je kasnije poslao na studij u Rim. ${ }^{28}$

O odluci da postane svećenik Josip Buturac je, između ostaloga, rekao: ,... nitko me nije trebao nagovarati, a gledajući razne ljudske poroke, od psovki pa dalje, htio sam da ljudima propovijedam ljudske kreposti i da se poroka moraju čuvati..."29 Zaređen je za svećenika 30. lipnja 1929. u Zagrebu, a mladu misu odslužio je 7. srpnja 1929. godine. ${ }^{30}$ Bila je to prva mlada misa u Ruševu nakon

\footnotetext{
Isto, zbirke pjesama (rukopisi): Slavujice, 1922. - 1925., Pjesme, 1925.

26

27 Isto.

28 Sinteza: Isto, Josip Buturac, Moja zapamćenja (rukopis), Lovrečina Grad, 1983., 34-3., 130; Isto, Josip Buturac, Zabilježbe - autobiografija Josipa Buturca po sjećanju i savjesti (rukopis), 29-39; J. BUTURAC 1994: 196-197; L. BUTURAC 2002: 13-14; DAMIŠ 1995: 294; PATAFTA 2017: 160 .

30 Sinteza: HR-DASB-PŽ-290, Osobni fond Josipa Buturca 1921. - 1995., kutija 2., Autobiografski materijal, Josip Buturac, Moja zapamćenja (rukopis), Lovrečina Grad, 1983., 37; Isto, Josip Buturac, Zabilježbe - autobiografija Josipa Buturca po sjećanju i savjesti (rukopis), 40-41; J. BUTURAC 1994: 197; DAMIŠ 1995: 294; PATAFTA 2017: 160.
} 
129 godina. Naime, prije Josipa Buturca mladu misu u Ruševu zadnji je slavio Đuro Feketa davne 1800. godine. ${ }^{31}$

Od 1929. do 1931. bio je kapelan u Kutini. Kao kapelan predavao je vjeronauk u osam škola (dvije u Kutini i šest u obližnjim selima). Bio je duhovnik orlovske i poslije križarske organizacije. S obzirom na dužnosti koje je kao kapelan vršio u Kutini, ipak je uspio odvojiti vrijeme za istraživački rad i pisanje te je objavio niz tekstova vezanih uz povijest požeškog kraja i drugih područja današnje Hrvatske. Od 1931. do 1934. godine bio je župnik u Čagliću. Riječ je o siromašnoj župi. Većina stanovnika na njezinu teritoriju bili su pravoslavni Srbi. U novoj župi susretao se s raznim problemima. Našao se u teškim materijalnim prilikama, a vjerski život župljana bio je na niskoj razini (život u izvanbračnim zajednicama, preljubi, zanemarivanje mise i ispovijedi, sudski procesi zbog svađa...). Kao rimokatolički svećenik imao je problematičan odnos sa starokatolicima. Pokušavao je zaustaviti prijelaze rimokatolika u Starokatoličku Crkvu. Ti prijelazi nisu poprimili masovne razmjere. Bio je u sukobu s lokalnim državnim službenicima, posebno s učiteljem Tanasijem Oblakovićem. Spomenuti učitelj katoličkim učenicima nije nabavio sve potrebne vjeronaučne knjige i oduzeo im je molitvenike. Sličan problem pojavio se i u Rogoljima. Ondje učenici rimokatoličke vjeroispovijesti, za razliku od pravoslavne djece, nisu imali vjeronaučne udžbenike. Buturac je predavao vjeronauk i u toj školi. Zahvaljujući intervencijama župnika, nadležne su vlasti povoljno riješile taj problem. Buturac kao mjesni župnik, protivno namjerama učitelja Oblakovića, katoličkoj djeci nije dopuštao pjevanje tijekom proslave Blagdana svetoga Save. Razlozi te zabrane, prema Buturčevim riječima, utemeljeni su na katoličkom nauku te na tadašnjim odnosima Katoličke i Srpske pravoslavne Crkve u Kraljevini Jugoslaviji, ali i na vjerskim prilikama u Čagliću. Još ranije, prije te izjave, napisao je banu, između ostaloga, da „Hrvati treba da ljube Srbe kao braću jednoga naroda... ali ne mogu i neće nikada priznati da je sv. Sava njihov svetac niti mogu biti prisiljavani da pjevaju pravoslavnu duhovnu pjesmu... "Imao je neugodnosti s općinskim bilježnikom i žandarima. Za lokalnu su vlast problem predstavljale neke župnikove izjave u propovijedima koje su doživljene kao opozicijsko ponašanje. U jednoj propovijedi komentirao je izjave nekog poslanika u Skupštini o katoličkim svećenicima. Poslanik je stvarno ili navodno rekao da treba uništiti isusovce i katoličke svećenike. O problemima u Župi Čaglić Buturac je objavio više članaka. Vrijedan znanstveni doprinos poznavanju djelovanja Josipa Buturca u toj župi dao je Ivica Miškulin spomenutim pisanim radom „Čaglićka epizoda - prilog životopisu Josipa Buturca“. Za svoja nastojanja Buturac nije uvijek nalazio potporu kolega svećenika, a o tome je napisao u knjizi Znaci vremena: „Kanonik Stjepan Korenić, Jugoslaven, pristaša

31 Požeške novine, 13. 7. 1929., 3-4. 
Pribićevićeve Samostalne demokratske stranke, nije htio sa mnom razgovarati o školskim prilikama u Čagliću, iako je bio kod N. D. Stola referent za katehizaciju. Generalni vikar biskup Premuš zamjerio je mojemu prikazivanju čaglićkih prilika u 'Katoličkom listu'. Kanonik Rožić prijateljski mi je priznao kako me kanonici smatraju svadljivcem u mojoj borbi za Crkvu i domovinu. Tako su mislile i neke redovnice. To je naša sudbonosna hrvatska šutnja, koja u svom kukavičluku napušta hrabre pojedince, čak ih zove svadljivcima." Dok je bio župnik u Čagliću, objavio je niz tekstova, a između ostalih, „Žiteljstvo Požeške kotline“ i „600 godišnjica slavonskih župa““. ${ }^{32}$ Buturac je od 1919. do 1940. godine sudjelovao u Hrvatskom katoličkom pokretu. ${ }^{33} \mathrm{Njegov}$ rad u tom pokretu predstavlja značajan problem budućih istraživanja.

Zagrebački nadbiskup Antun Bauer poslao je Buturca na studij u Rim. ${ }^{34} \mathrm{Od}$ 1934. do 1936. godine u Rimu je studirao crkvenu povijest i pomoćne povijesne znanosti te stekao licencijatsku diplomu na Pontificia vniversitas Gregoriana koja je pohranjena u Državnom arhivu u Slavonskom Brodu - Odjelu u Požegi. ${ }^{35}$ Tijekom studija u Rimu posjećivao je arhivske ustanove i proučavao relevantne izvore za svoje pisane radove. U vatikanskom arhivu izučavao je popis župa Požeškog arhiđakonata za razdoblje od 1332. do 1335. godine. ${ }^{36} \mathrm{Na}$ stropu vatikanskog arhiva uočio je sliku koja prikazuje krunidbu kralja Zvonimira, odnosno njegovu prisegu u nazočnosti papinog izaslanika Gebisona. ${ }^{37}$ Ta je slika više

\footnotetext{
Sinteza: AFSP, Ostavština Josipa Buturca, Isprave dr. Josipa Buturca I., Nadbiskupski duhovni stol, broj 1827-1931., Zagreb, 27. 2. 1931.; HR-DASB-PŽ-290, Osobni fond Josipa Buturca 1921. - 1995., kutija 2., Autobiografski materijal, Josip Buturac, Moja zapamćenja (rukopis), Lovrečina Grad, 1983., 38-45; Isto, Josip Buturac, Zabilježbe - autobiografija Josipa Buturca po sjećanju i savjesti (rukopis), 42-74; Isto, kutija 4., Josip Buturac, Moja zapamćenja (rukopis pisan pisaćim strojem), I. dio, 37, 57; II. dio, 15; III. dio, 9, 33, 34, 35; J. BUTURAC 1932a: 18-20; ISTI 1932b: 236-238; ISTI 1935a: 472-474; ISTI 1994: 197-200; L. BUTURAC 2002: 15-16, 39-41; MIŠKULIN 2010: 87-113; PATAFTA 2017: 161. (Uz navedene izvore i literaturu u prikazu Buturčeva rada u čaglićkoj župi ponajviše sam se oslanjao na pisani rad Ivice Miškulina „Čaglićka epizoda - prilog životopisu Josipa Buturca“, MIŠKULIN 2010)

33 Sinteza: HR-DASB-PŽ-290, Osobni fond Josipa Buturca 1921. - 1995., kutija 4., Josip Buturac, Oko spora u Katoličkoj akciji među Hrvatima (rukopis pisan pisaćim strojem); MIŠKULIN 2010: 88 .

34 Detaljnije o studiju u Rimu u HR-DASB-PŽ-290, Osobni fond Josipa Buturca 1921. - 1995., kutija 2., Autobiografski materijal, Josip Buturac, Moja zapamćenja (rukopis), Lovrečina Grad, 1983., 46-47; Isto, Josip Buturac, Zabilježbe - autobiografija Josipa Buturca po sjećanju i savjesti (rukopis), 75-83; Isto, kutija 4., Josip Buturac, Moja zapamćenja (rukopis pisan pisaćim strojem), I. dio, 38 .

35 HR-DASB-PŽ-290, Osobni fond Josipa Buturca 1921. - 1995., kutija 1., Osobni dokumenti, Pontificia Vniversitas Gregoriana, Rim, 25. lipnja 1936.; DAMIŠ 1995: 294; RADONIĆ 2008 2, 9 .

36 HR-DASB-PŽ-290, Osobni fond Josipa Buturca 1921. - 1995., kutija 2., Autobiografski materijal, Josip Buturac, Zabilježbe - autobiografija Josipa Buturca po sjećanju i savjesti (rukopis), 77; L. BUTURAC 2002: 16.

37 Isto, 78; ANGELIS 2011: 93-94; J. BUTURAC 1994: 201; L. BUTURAC 2002: 17.
} 
puta objavljena u obliku razglednice te u nekim publikacijama poput Danice iz 1937. godine. ${ }^{38}$ Josip Buturac vratio se u Kraljevinu Jugoslaviju 1936. godine. ${ }^{39}$

Ubrzo nakon povratka iz Rima, radi stjecanja formalne kvalifikacije za profesora Nadbiskupske gimnazije, upisao je studij na Filozofskom fakultetu u Zagrebu, pod A opću povijest, $\mathrm{B}$ nacionalnu povijest, $\mathrm{C}$ pomoćne povijesne znanosti, latinski jezik i etnologiju. Kasnije je, u razgovorima sa suvremenicima, volio istaknuti da su mu profesori bili eminentni stručnjaci poput povjesničara i arheologa Grge Novaka, etnologa Milovana Gavazzija i povjesničara Ljudmila Hauptmanna. Kao student povijesti i etnologije, svoje je profesore doživljavao kao kolege, a ponekad ih je i ispravljao. Pod mentorstvom Ferde Šišića napisao je opsežan seminarski rad Povijest Zbora duhovne mladeži zagrebačke 1836-1936. koji je objavljen 1937. godine. Godinu dana kasnije objavio je Kartu zagrebačke nadbiskupije u pet boja i mjerilu 1 : 200 000. Prema riječima Daniela Patafte, njezina vrijednost ,je u tome što donosi ubikacijske podatke o nekadašnjim propalim samostanima, župama, crkvama i kapelama, a sve na temelju manje poznatih objavljenih i neobjavljenih izvora." Neko vrijeme Josip Buturac bio je tajnik te prefekt u Dječačkom sjemeništu. Predavao je vjeronauk i povijest u Nadbiskupskoj gimnaziji. Položio je ispite iz etnologije, pedagogije i nacionalne povijesti, ali opću povijest nije položio jer su isusovci 1939. preuzeli Nadbiskupsku gimnaziju. Tada je postao arhivistom u Nadbiskupskoj kancelariji, a radio je i na sređivanju Nadbiskupskog arhiva. Krajem tridesetih godina objavio je niz tekstova u raznim publikacijama poput Katoličkog lista. ${ }^{40}$

\section{Život i karijera u Drugom svjetskom ratu i socijalističkoj Jugoslaviji}

Uz pomoć kipara Ivana Meštrovića i podbana Banovine Hrvatske Ive Krbeka te na preporuku Alojzija Stepinca, krajem 1940. godine primljen je u Arhiv u Zagrebu, odnosno Državni arhiv kao kaptolski arhivist ${ }^{41}$, a počeo je raditi 2. siječnja

38 Sinteza: HR-DASB-PŽ-290, Osobni fond Josipa Buturca 1921. - 1995., kutija 2., Autobiografski materijal, Josip Buturac, Zabilježbe - autobiografija Josipa Buturca po sjećanju i savjesti (rukopis), 78; J. BUTURAC 1994: 201; L. BUTURAC 2002: 17, 43. stol, broj 144/Pr., Zagreb, 8. 11. 1936.; Isto, Isprave dr. Josipa Buturca I., Nadbiskupski duhovn stol, broj 182/Pr., Zagreb, 1. 9. 1937.; Isto, Isprave dr. J. B. II., Nadbiskupski duhovni stol, broj 123/Pr., Zagreb, 28. 6. 1939.; HR-DASB-PŽ-290, Osobni fond Josipa Buturca 1921. - 1995., kutija 2., Autobiografski materijal, Josip Buturac, Moja zapamćenja (rukopis), Lovrečina Grad, 1983., 49-56, 132; Isto, Josip Buturac, Zabilježbe - autobiografija Josipa Buturca po sjećanju i savjesti (rukopis), 85-89; Isto, kutija 4., Josip Buturac, Moja zapamćenja (rukopis pisan pisaćim strojem), I. dio, 39; ANGELIS 2011: 94-95; J. BUTURAC 1994: 201-202; L. BUTURAC 2002: 18-19, 44-46; DAMIŠ 1995: 294; PATAFTA 2017: 162-163, 166.

41 Stariji dio Kaptolskog arhiva pohranjen je 1916. u Zemaljskom arhivu (Sinteza: HR-DASB-PŽ-290, Osobni fond Josipa Buturca 1921. - 1995., kutija 2., Autobiografski materijal, Josip Buturac, Moja zapamćenja (rukopis), Lovrečina Grad, 1983., 55; J. BUTURAC 1994: 161-162, 203). 
1941. godine. ${ }^{42}$ Suurednikom Katoličkog lista imenovan je 1937., ali do 1939. godine, zbog studija na Filozofskom fakultetu, zamjenjivao ga je Juraj Paša. ${ }^{43} \mathrm{Tu}$ dužnost obavljao je i tijekom Drugog svjetskog rata.

Buturac se pripremao za polaganje doktorskog ispita i radio na svom doktorskom radu. Uspješno je položio doktorski ispit i 16. rujna 1944. obranio doktorsku disertaciju na Rimokatoličkom bogoslovskom fakultetu u Zagrebu pod naslovom Katolicka Crkva u Slavoniji za turskog vladanja, a nekoliko dana kasnije, u Rektoratu Sveučilišta u Zagrebu, svečano je uveden u zvanje doktora znanosti. Primljen je kao honorarni predavač crkvene povijesti na Rimokatoličkom bogoslovskom fakultetu radom Zagrebački biskupi i nadbiskupi 1094 - 1944. godine. Imenovan je u zvanje privatnog docenta pri Katedri za crkvenu povijest. ${ }^{44}$

Dana 21. studenoga 1944. Buturčevu obitelj pogodila je tragedija. Naime, njegov brat Karlo poginuo je kao partizan nedaleko od Našica. ${ }^{45}$ Godine 1946. uhićen je njegov brat Antun, a ,milicioneri su ga vodili prema željezničkoj stanici u Čaglinu s namjerom da ga odvedu u Požegu i predaju sudu. Međutim, oni su ga pred visokim nasipom željezničke pruge u Čaglinu ubili sa 16 metaka (rafalom iz strojnice). Kasnije su se izgovarali da je htio bježati. To je bila obična lažna izlika, jer je bio vezan zajedno sa ženskom osobom i jer su se nalazili pred nasipom ('zidom'). Mjesni narodni odbor u Čaglinu bio je ogorčen zbog ovakvoga ubojstva pa je tražio da iz Požege dođe komisija i obavi istragu. Komisija je došla, sastavila zapisnik i obećala majci naknadno javiti kako je i zašto došlo do ovoga ubojstva. ${ }^{\text {“46 }}$ Milicioneri su premješteni, a okolnosti ubojstva nikada nisu utvrđene. ${ }^{47}$ Buturčev brat Antun nastradao je zbog planiranja ilegalnog bijega preko granice ${ }^{48}$,

$42 \quad$ Sinteza: AFSP, Ostavština Josipa Buturca, Isprave dr. J. B. II., Banska vlast Banovine Hrvatske Odjel za prosvjetu u Zagrebu, broj: 104851-II-1940., Zagreb, 21. 12. 1940.; HR-DASB-PŽ-290, Osobni fond Josipa Buturca 1921. - 1995., kutija 2., Autobiografski materijal, Josip Buturac, Moja zapamćenja (rukopis), Lovrečina Grad, 1983., 132; Isto, kutija 4., Josip Buturac, Moja zapamćenja (rukopis pisan pisaćim strojem), II. dio, 27; J. BUTURAC 1994: 205; L. BUTURAC 2002: 21; PATAFTA 2017: 163.

43 AFSP, Ostavština Josipa Buturca, Isprave dr. Josipa Buturca I., Nadbiskupski duhovni stol, broj 184/Pr., Zagreb, 3. 9. 1937.; Isto, Isprave dr. Josipa Buturca I., Nadbiskupski duhovni stol, broj 115/Pr., Zagreb, 10. lipnja 1939.; Isto, Isprave dr. J. B. II., Nadbiskupski duhovni stol, broj 123/ Pr., Zagreb, 28. 6. 1939.

44 Sinteza: HR-DASB-PŽ-290, Osobni fond Josipa Buturca 1921. - 1995., kutija 1., Osobni dokumenti, Nezavisna Država Hrvatska, Odjel za visoku nastavu, broj 69847-1944., Zagreb, 21 11. 1944.; Isto, kutija 2., Autobiografski materijal, Josip Buturac, Moja zapamćenja (rukopis), Lovrečina Grad, 1983., 75; Isto, Josip Buturac, Zabilježbe - autobiografija Josipa Buturca po sjećanju i savjesti (rukopis), 106-107; J. BUTURAC 1994: 207; L. BUTURAC 2002: 19-20.

45 HR-DASB-PŽ-290, Osobni fond Josipa Buturca 1921. - 1995., kutija 2., Autobiografski materijal, Josip Buturac, Zabilježbe - autobiografija Josipa Buturca po sjećanju i savjesti (rukopis), 109. Nije naveo zašto i pod kakvim je okolnostima njegov brat Karlo otišao u partizane.

46 Isto, 118

47 Isto.

48 Isto 
iako je, po svemu sudeći, bio vojnik Jugoslavenske armije, a Josip Buturac o tome je zabilježio: „1945, 8. VIII. brat Tuna u vojničkoj partizanskoj uniformi dolazi k meni poslije duljeg vremena i pripovijeda ratne doživljaje.“49

Nakon političkih promjena i dolaska komunista na vlast 1945. godine, Josip je, prema riječima Lojze Buturca, označen kao nepodoban jer bi zbog prenaglašene nacionalne orijentacije mogao negativno utjecati na bogoslove pa je zbog toga bio prihvatljiv za rad u arhivu, ali ne i na Rimokatoličkom bogoslovskom fakultetu. ${ }^{50}$ U knjizi Znaci vremena Josip Buturac ovako je objasnio razlog svoga odlaska s fakulteta: „Kada se rat svršio, i u novoj državi Ministarstvo prosvjete (Hrdlička) hoće da sa mnom sklopi ugovor o predavanjima na Bogoslovskom fakultetu, ali prof. Kniewald to osujećuje tvrdnjom da je Buturac za vrijeme rata bio poticatelj borbe protiv komunista. U to nitko ne vjeruje, jer je Buturac bio proganjan od ustaških vlasti. Kniewald, uza svoje dvije katedre, preuzima i predavanja iz crkvene povijesti. ${ }^{\text {"51 }} \mathrm{Na}$ temelju analize nekoliko Buturčevih tekstova objavljenih u doba ustaškog režima sasvim je jasno da primjedba svećenika Dragutina Kniewalda nije neutemeljena. Detaljna analiza toga problema slijedi na drugome mjestu ovoga rada. Početkom 1952. Rimokatolički bogoslovski fakultet isključen je iz sastava Sveučilišta u Zagrebu, ${ }^{52}$ a profesori su prestali primati državne plaće pa je Josip Buturac 1953. besplatno angažiran kao predavač crkvene povijesti i pomoćnih povijesnih znanosti. ${ }^{53}$ Primljen je u zvanje izvanrednog profesora 1958. godine, a tijekom svoga rada izveo je deset doktora znanosti. ${ }^{54} \mathrm{Na}$ vlastiti zahtjev razriješen je službe na fakultetu 1962. godine zbog dobi, narušenog zdravlja i obveza u arhivskoj službi. ${ }^{55}$

$49 \quad$ Isto, 110.

50 L. BUTURAC 2002: 20. Komunističke su vlasti 1945. bile spremne sklopiti s Josipom Buturcem ugovor o predavanjima na Rimokatoličkom bogoslovskom fakultetu, a optužbe da je „koljač“ i ustaša dolazile su od pojedinaca iz crkvenih krugova. Takve optužbe prihvatio je i svećenik Svetozar Rittig. HR-DASB-PŽ-290, Osobni fond Josipa Buturca 1921. - 1995., kutija 2., Autobiografski materijal, Josip Buturac, Moja zapamćenja (rukopis), Lovrečina Grad, 1983., 76; Isto, kutija 4., Josip Buturac, Moja zapamćenja (rukopis pisan pisaćim strojem), III. dio, 12.

51 J. BUTURAC 1994: 208.

52 AKMADŽA 2013: 127.

53 HR-DASB-PŽ-290, Osobni fond Josipa Buturca 1921. - 1995., kutija 1., Osobni dokumenti, Rimokatolički bogoslovski fakultet u Zagrebu, broj 504/1953., Zagreb, 15. 10. 1953.; Isto, kutija 2., Autobiografski materijal, Josip Buturac, Moja zapamćenja (rukopis), Lovrečina Grad, 1983. 77-79; Isto, Josip Buturac, Zabilježbe - autobiografija Josipa Buturca po sjećanju i savjesti (rukopis), 154; J. BUTURAC 1994: 208; L. BUTURAC 2002: 20.

54 Sinteza: HR-DASB-PŽ-290, Osobni fond Josipa Buturca 1921. - 1995., kutija 1., Osobni dokumenti, dopis nadbiskupa koadjutora i velikog kancelara Rimokatoličkog bogoslovskog fakulteta u Zagrebu Franje Šepera Josipu Buturcu, broj 1/K/58., Zagreb, 9. 1. 1958.; Isto, kutija 2., Autobiografski materijal, Josip Buturac, Moja zapamćenja (rukopis), Lovrečina Grad, 1983. 78; J. BUTURAC 1994: 208; L. BUTURAC 2002: 20.

55 Sinteza: HR-DASB-PŽ-290, Osobni fond Josipa Buturca 1921. - 1995., kutija 2., Autobiografski materijal, Josip Buturac, Moja zapamćenja (rukopis), Lovrečina Grad, 1983., 78; PATAFTA 2017: 164 . 
Godine 1943. položio je stručni arhivistički ispit. ${ }^{56}$ Predano je radio kao arhivist Kaptolskog arhiva u Državnom arhivu, odnosno Arhivu Hrvatske u kojem je bio zaposlen do mirovine 1966. godine. ${ }^{57}$ Godine 1947. postao je viši arhivist bibliotekarsko-arhivističke struke. ${ }^{58}$ Napisao je nekoliko samostalnih djela te oko petnaest članaka koji se odnose na arhivsku problematiku. ${ }^{59}$ Prvi je u Hrvatskoj stručno pisao o problemima s područja arhivistike te stvarao hrvatsku arhivističku terminologiju. ${ }^{60}$ Ovdje treba spomenuti njegovo prvo objavljeno zasebno djelo iz arhivistike, a radi se o Arhivskoj čitanci publiciranoj 1950. godine. ${ }^{61}$ Lojzo Buturac je u svojoj knjizi Život i djelo dr. Josipa Buturca (1905.-1993.) napisao da je Arhivska čitanka prva knjiga s područja arhivistike koja je objavljena u Hrvatskoj, a Josip Buturac napisao je da je Arhivska čitanka, ,više godina bila jedini priručnik iz arhivistike za Jugoslaviju. “62 Potonji je u Beogradu sudjelovao u raspravi o nacrtu arhivskog zakona socijalističke Jugoslavije. ${ }^{63}$ Također je sudjelovao u pripremi

56 HR-DASB-PŽ-290, Osobni fond Josipa Buturca 1921. - 1995., kutija 1., Osobni dokumenti, Svjedočba, broj 10-1943., Zagreb, 1. 6. 1943.; Isto, kutija 2., Autobiografski materijal, Josip Buturac, Moja zapamćenja (rukopis), Lovrečina Grad, 1983., 74; L. BUTURAC 2002: 21.

57 J. BUTURAC 1994: 205-207; L. BUTURAC 2002: 21; DAMIŠ 1995: 294-295; PATAFTA 2017: 163-164.

58 AFSP, Ostavština Josipa Buturca, Isprave dr. J. B. II., Narodna Republika Hrvatska, Ministarstvo prosvjete, broj: 86107-1947., Zagreb 31. 12. 1947.; Sâm Josip Buturac u rukopisu Zabilježbe - autobiografija Josipa Buturca po sjećanju i savjesti (rukopis) i Lojzo Buturac u knjizi Život i djelo dr. Josipa Buturca naveli su da je promaknut u zvanje višega arhivista 1962. godine (HRDASB-PŽ-290, Osobni fond Josipa Buturca 1921. - 1995., kutija 2., Autobiografski materijal, Josip Buturac, Zabilježbe - autobiografija Josipa Buturca po sjećanju i savjesti (rukopis), 182; L. BUTURAC 2002: 21). U nizu dokumenata pohranjenih u Arhivu Franjevačkog samostana u Požegi od 1947. do 1962. godine, uz ime i prezime Josipa Buturca stoji da je bio viši arhivist (AFSP, Ostavština Josipa Buturca, Isprave dr. J. B. II., Narodna Republika Hrvatska, Ministarstvo prosvjete, broj: 86107-1947., Zagreb, 31. 12. 1947.; Isto, Narodna Republika Hrvatska, Komitet za naučne ustanove, Sveučilište i visoke škole, broj: 13274, Zagreb, 25. 8. 1949.; Isto, Narodna Republika Hrvatska, Državni arhiv u Zagrebu, broj: 292-1951., Zagreb, 5. 4. 1951.; Isto, Savjet za prosvjetu, nauku i kulturu, broj: 5907-1952., 5. 5. 1952.; Isto, Josip Buturac Ravnateljstvu Državnog arhiva u Zagrebu, 19. 5. 1954...).

59 L. BUTURAC 2002: 21; DAMIŠ 1995: 295.

60 L. BUTURAC 2002: 21; DAMIŠ 1995: 295; PATAFTA 2017: 171.

61 HR-DASB-PŽ-290, Osobni fond Josipa Buturca 1921. - 1995., kutija 2., Autobiografski materijal, Josip Buturac, Zabilježbe - autobiografija Josipa Buturca po sjećanju i savjesti (rukopis), 140-141; L. BUTURAC 2002: 21; DAMIŠ 1995: 297.

62 HR-DASB-PŽ-290, Osobni fond Josipa Buturca 1921. - 1995., kutija 2., Autobiografski materijal, Josip Buturac, Zabilježbe - autobiografija Josipa Buturca po sjećanju i savjesti (rukopis), 141; L. BUTURAC 2002: 21. Detaljnije o arhivističkim radovima Josipa Buturca u PATAFTA 2017: 171-173.

63 HR-DASB-PŽ-290, Osobni fond Josipa Buturca 1921. - 1995., kutija 2., Autobiografski materijal, Josip Buturac, Zabilježbe - autobiografija Josipa Buturca po sjećanju i savjesti (rukopis), 138; Glas koncila, 1. 8. 1993., 2; L. BUTURAC 2002: 21-22. 
zbirke dokumenata Zaključci Hrvatskog sabora ${ }^{64}$ U razdoblju od 1953. do 1963. godine vodio je tečajeve za arhivsku službu i pomoćne povijesne znanosti u Državnom arhivu. O problemima vezanim uz arhivistiku održavao je predavanja na tečajevima Historijskog instituta Jugoslavenske akademije znanosti i umjetnosti i bio ispitivač na stručnim ispitima iz arhivske službe. O pitanjima i problemima arhivistike više puta govorio je kao gost Radio Zagreba i Radio Vrbovca. Napisao je i pet predavanja za Radio Beograd. Sudjelovao je na znanstvenim i stručnim skupovima diljem Jugoslavije. Bio je instruktor i nadzornik mnogih arhiva u Hrvatskoj ${ }^{65}$ Od 1948. do 1958. godine bio je jedan od sudionika pregovora o povratku vrijedne arhivske građe iz Mađarske. ${ }^{66} \mathrm{O}$ pregovorima s Mađarima razgovarao je u veljači 1993. godine s novinarom Ivanom Jakovinom te požeškim arhivistima Tomislavom Radonićem i Rudolfom Helijem u Lovrečina Gradu, a taj je razgovor, uz Buturčevo dopuštenje, zabilježen na magnetofonskoj vrpci. ${ }^{67}$

Od samostalnih djela koja treba istaknuti i neke još jednom navesti jesu: Karta zagrebačke nadbiskupije (1938.), Arhivska čitanka (1950.), Pregled povijesti Katoličke Crkve (1961.), proširena verzija njegove disertacije Katolička Crkva u Slavoniji za turskoga vladanja (1970.), Stanovništvo Požege i okolice (1700.1950.) (1967. i 2004.), Crkveno-kulturna povijest Požege i okolice 1227-1977. (1977.), Božjakovina-Brckovljani 1209- 1980 (1981.), Marija Bistrica 1209-1980 (1981.), Stubica Donja i Gornja 1209 - 1982. (1982.), Regesta za Spomenike Požege i okolice 1221 - 1860 (1990.), Znaci vremena - Rasprave iz hrvatske crkvene prošlosti (1932-1945) (1994.), Pisani spomenici Požege i okolice 12101536. (1995.). Treba navesti i poznatu knjigu Poviest crkve u Hrvatskoj koju je Buturac objavio zajedno s Krunoslavom Draganovićem 1944. godine te knjigu Povijest Katoličke Crkve među Hrvatima (1973.) s Antunom Ivandijom. Djelo Iz historije pisanog dokumenta (1966.) objavio je sa Stjepanom Bačićem. Spomenuo bih i skripte za studente: Povijesna metodologija (1956.) i Latinska paleografija (1960.). Josip Buturac autor je više od 30 objavljenih samostalnih djela. ${ }^{68}$ Pisao je o prošlosti Zagrebačke biskupije (nadbiskupije) te njezinih biskupa i nadbisku-

64 L. BUTURAC 2002: 22; DAMIŠ 1995: 295; PATAFTA 2017: 172. Prema trojici navedenih autora, Josip Buturac sudjelovao je u pripremi svezaka I.-IV. zbirke dokumenata Zaključci Hrvatskog sabora, objavljenih od 1958. do 1965. godine. Svezak IV. izašao je 1964., a Buturac je sudjelovao u pripremi i V. (1966.), VI. (1968.) te VII. sveska (1970.). Dakle, sudjelovao je u pripremi prvih sedam svezaka (Zaključci Hrvatskog sabora, sv. I.-VII., 1958. - 1970.).

Sinteza: L. BUTURAC 2002: 21-22; DAMIŠ 1995: 295.

HR-DASB-PŽ-290, Osobni fond Josipa Buturca 1921. - 1995., kutija 4., Josip Buturac, Moja zapamćenja (rukopis pisan pisaćim strojem), III. dio, 38; Isto, kutija 2., Autobiografski materijal, Josip Buturac, Moja zapamćenja (rukopis), Lovrečina Grad, 1983., 83; J. BUTURAC 1994: 207; L. BUTURAC 2002: 22.

Požeški list, 25. 2. 1993., 9.

Sinteza: J. BUTURAC 1994: 211; L. BUTURAC 2002: 31-91, 111-113; DAMIŠ 1995: 297-298, 316-317. 
pa ${ }^{69}$ Bavio se i poviješću redovničkih zajednica u Hrvatskoj poput benediktinaca, ivanovaca, templara, franjevaca, augustinaca, pavlina, isusovaca. ${ }^{70}$ Tijekom svoga dugogodišnjeg znanstvenog i publicističkog rada objavljivao je u mnogim znanstvenim, stručnim i novinskim publikacijama. ${ }^{71}$ Bio je jedan od suradnika i autora Hrvatske enciklopedije, Enciklopedije Jugoslavije, Hrvatskog biografskog leksikona i Požeškog leksikona. ${ }^{72}$ Za Požeški leksikon samostalno je napisao 185 natuknica, a još 53 sa suradnicima. ${ }^{73}$ Bio je i član Onomastičkog odbora pri Institutu za jezik i član Odbora za narodni život i običaje pri Etnološkom zavodu Jugoslavenske akademije znanosti i umjetnosti. ${ }^{74}$ Iako mu je predbačena bliskost s vladajućom komunističkom elitom, ${ }^{75}$ tvrdio je da nije postao član JAZU zbog kršćanskih uvjerenja. ${ }^{76}$

Bio je vezan uz zavičaj u kojem je rođen i odrastao, a to se najbolje može uočiti uvidom u njegovu pisanu ostavštinu. Naime, najviše pisanih radova koje je objavio za života, kako je dobro primijetio i argumentirao Lojzo Buturac, u odnosu na ostale dijelove Hrvatske, tematski su vezani uz povijest Požeške kotline. ${ }^{77}$ Neka od njegovih poznatih djela, koja se odnose na požeški kraj, već su spomenuta u ovom radu pa ih nije potrebno ponovno navoditi.

Kao povjesničar i publicist dobio je brojna priznanja zbog značajnog doprinosa u rasvjetljavanju problema kojima se bavio. Brončanu značku 1984. dodijelio

\footnotetext{
69 DAMIŠ 1995: 295; L. BUTURAC 2002: 42, 44-47, 49-56, 59, 65, 74-77, 82-85, 87-91.

70 DAMIŠ 1995: 295; L. BUTURAC 2002: 40, 44, 47-48, 52, 55, 57, 59, 69, 74.

${ }_{71}$ Anđeo čuvar, Arhivski vjesnik, Bjelovarski list, Bjelovarski zbornik, Bogoslovska smotra, Crkva u svijetu, Croatia sacra, Croatica Christiana Periodica, Čazma-zbornik, Danica-kalendar, Ekonomski zbornik, Glas koncila, Glasnik Srca Isusova i Marijina, Glasnik svetog Josipa, Historijski zbornik, Hrvatska prosvjeta, Hrvatska prošlost, Hrvatska smotra, Hrvatska straža, Katolički list, Katolički tjednik, Komuna, Krijes, Križevački zbornik, Kršśanska škola, Kulturno-prosvjetni zbornik, Luč, Ljetopis JAZU, Marija, Marulić, Međimurje, Mladost, Muzejski vjesnik (Križevci), Muzeum (Brno), Narodna politika, Naša domovina, Naša Gospa Lurdska, Nedjeljne vijesti, Obitelj, Obnovljeni život, Obzor, Odjek, Spomenica Nadbiskupske gimnazije, Starine JAZU, Subotičke novine, Travničko smilje, Traženja - časopis za književnost kulturu $i$ društvena pitanja, Veritas, Vjesnik Đakovačke biskupije, Vjesnik Historijskog arhiva Slavonska Požega i Muzeja Požeške kotline, Vjesnik Hrvatskog državnog arhiva, Vjesnik Nadbiskupije splitsko-makarske,Vjesnik Zagrebačke nadbiskupije, Vrbovečki zbornik, Za dom, Zagreb, Zborni kaptol, Zbornik za narodni život i običaje, Zumbuli i Zvona (L. BUTURAC 2002: 31-91; Isto: 114-119; DAMIŠ 1995: 298-320).

72 L. BUTURAC 2002: 55-59, 64, 68-71, 74, 76-77, 82-84.

73 Požeški leksikon 1977: 11-360.

74 J. BUTURAC 1990a: 321; ISTI 1990b: 104; DAMIŠ 1995: 297; RADONIĆ 2008: 4; PATAFTA 2017: 165.

75 Nije naveo tko mu je točno predbacio bliskost s komunistima riječima: „Ti si njihov!“ (HRDASB-PŽ-290, Osobni fond Josipa Buturca 1921. - 1995., kutija 2., Autobiografski materijal, Josip Buturac, Moja zapamćenja (rukopis), Lovrečina Grad, 1983., 123).

76 Isto.

77 L. BUTURAC 2002: 25-26.
} 
mu je Savez društava arhivskih radnika Hrvatske. ${ }^{78}$ Plaketu Muzejskog društva iz Varaždina dobio je 1987. godine. ${ }^{79}$ Skupština općine Vrbovec dodijelila mu je 1989. Spomenicu oslobođenja općine Vrbovec sa zlatnim klasovima ,u znak priznanja i naročiti doprinos za socijalistički razvitak općine Vrbovec i postignute uspjehe u radu za dobro i napredak zajednice." ${ }^{\text {"80 }}$ Iste godine imenovan je dekretom zagrebačkog nadbiskupa kardinala Franje Kuharića počasnim kanonikom Prvostolnog Kaptola zagrebačkog. ${ }^{81}$ Godine 1990. u Slavonskoj Požegi dobio je nagradu „Miroslav Kraljević“ koju mu je dodijelilo Društvo novinara Hrvatske. ${ }^{82}$ Prilikom proslave 740 godina grada Križevaca 1993. godine primio je „Povelju počasnog građanina grada Križevaca“. ${ }^{83}$ Posmrtno je dobio plaketu i „Nagradu grada Požege za životno djelo“ ${ }^{84}$ Društvo za hrvatsku povjesnicu u Požegi je 1993. godine, zbog doprinosa u istraživanju prošlosti Požeške kotline, proglasilo Josipa Buturca začasnim članom. ${ }^{85}$ Državni arhiv u Slavonskom Brodu - Odjel u Požegi, pod vodstvom Tomislava Radonića, njeguje sjećanje na Buturca, a o tome, između ostaloga, svjedoči i izložba koja je održana od 28. studenoga do 6. prosinca 2008. godine u Gradskom muzeju Požega o temi života i rada Josipa Buturca. Povodom spomenute izložbe otisnut je i katalog pod naslovom Život i djelo dr. Josipa Buturca (1905.-1993.) autora Tomislava Radonića.

Buturac se osvrnuo na svoj znanstveni rad u razgovoru za Veritas u lipnju 1985. godine riječima: „U svom književnom i znanstvenom radu dao sam naoko puno, a zapravo malo! Uvijek sam, naime, bio prenatrpan raznim tehničkim dužnostima, koje sam nastojao savjesno i vršiti. Nemojte nipošto misliti da se time ispričavam zbog propusta na znanstvenom polju. Ali uzmite npr. činjenicu da sam u svom zavičajnom selu pomagao gradnju kapele, dvaju poljskih križeva, a u nekom drugom selu, nije važno ime, organizirao sam i pomagao gradnju kuće za siromašnu obitelj, vodio sam mljekarsku zadrugu u Čagliću, svećeničku menzu u Zagrebu, predavao na Bogoslovnom fakultetu u Zagrebu više godina i uređivao Nadbiskupski arhiv u Zagrebu - i sve to besplatno - onda Vam postaje

\footnotetext{
78 RADONIĆ $2008: 9$.

79 L. BUTURAC 2002: 27.

80 HR-DASB-PŽ-290, Osobni fond Josipa Buturca 1921. - 1995., kutija 1., Osobni dokumenti, Spomenica oslobođenja općine Vrbovec sa zlatnim klasovima, broj 2192-01-/89-1, Vrbovec, 6. svibnja 1989.

81 Isto, zagrebački nadbiskup, broj 172-Prez./89, Zagreb, 31. listopada 1989.; L. BUTURAC 2002: 28; RADONIĆ 2008: 9.

82 L. BUTURAC 2002: 28; Požeški list, 29. 3. 1990., 5; Isto, 19. 4. 1990., 8; Isto, 26. 4. 1990., 1; Isto, 10. 5. 1990., 2; Isto, 14. 10. 1993., 8; RADONIĆ 2008: 5.

83 L. BUTURAC 2002: 28.

84 Isto: 29; RADONIĆ 2008: 5.

85 Požeški list, 14. 10. 1993., 8; RADONIĆ 1994: 72; ISTI 2008: 5.
} 
jasnije zašto nisam mogao svoje znanstvene projekte po svojoj volji ostvariti. Nakon očeve smrti preuzeo sam brigu za šestero mlađe braće, a službovao sam i na najsiromašnijoj župi u nadbiskupiji.“" ${ }^{\circ 6}$ Sudeći po ovoj izjavi, ali i na temelju objavljene i neobjavljene pisane ostavštine autobiografskog karaktera kojom sam se koristio tijekom pisanja ovoga članka, nema nikakve dvojbe da je život Josipa Buturca bio obogaćen različitim aspektima izvan njegova svećeničkog poziva te znanstvenog rada i arhivske djelatnosti.

Svoje umirovljeničke dane proveo je kao duhovnik časnih sestara u Lovrečina Gradu kod Vrbovca. ${ }^{87}$ Mir samostana u kojem je živio pogodno je djelovao na njegov historiografski rad kojem se gotovo posvećeno predao do kraja života. Preminuo je 5. listopada 1993. godine ${ }^{88}$ Sahranjen je u Ruševu. ${ }^{89}$ Prilikom posljednjeg ispraćaja u Lovrečina Gradu od Josipa Buturca oprostio se nadbiskup zagrebački, kardinal Franjo Kuharić, a u Ruševu biskup Đuro Kokša i poznati arhivist Andrija Lukinović..$^{90}$

\section{Ideje i predodžbe o ustaškom režimu, četnicima, partizanima i Srbima}

O prilikama u doba ustaškoga režima i osobnim nevoljama koje su ga tada snašle Buturac je govorio Arisu Angelisu 1993. godine kao gost na Hrvatskom radiju u emisiji Ljudi dvadesetog stoljeća. Kao svjedok prošlosti, rekao je da „Pavelić i njegovi ustaše provode okrutnu diktaturu“ te da je zagrebački nadbiskup ,protivnik takve diktature koja progoni Srbe, Židove, Rome, a i komuniste progone bez prave potrebe“. Nadalje je, između ostaloga, naveo kako je Katolički list morao „koji put donijeti Pavelićevu sliku, ali smo to nerado činili i zbog toga smo bili trn u oku ustašama, koji su govorili da Katolički list mora biti ili ustaški ili ga ne treba biti. Kanonik Lončar je nešto malo prigovorio ustašama i bio osuđen na smrt, pa mu je kazna smanjena za 18 godina Lepoglave“ “.91 Josipa Buturca je, prema njegovim riječima, ustaška vlast optužila za veleizdaju zbog teksta „Naturalizacija“ koji su vlastodršci protumačili kao napad na talijanske okupatore te je očekivao da će ga deportirati u Jasenovac. Tada se skrivao po

\footnotetext{
$86 \quad$ Veritas - revija svetoga Antuna Padovanskog, lipanj 1985., br. 6.

87 HR-DASB-PŽ-290, Osobni fond Josipa Buturca 1921. - 1995., kutija 2., Autobiografski materijal, Josip Buturac, Moja zapamćenja (rukopis), Lovrečina Grad, 1983., 127-128; ANGELIS 2011: 91; J. BUTURAC 1994: 209; L. BUTURAC 2002: 24; DAMIŠ 1995: 295.

88 HR-DASB-PŽ-290, Osobni fond Josipa Buturca 1921. - 1995., kutija 1., osmrtnica; Požeški list, 14. 10. 1993., 8; RADONIĆ 1994: 72-73; Sisački tjednik, 14. 10. 1993., 13.

89 L. BUTURAC 2002: 29; Požeški list, 14. 10. 1993., 8; Sisački tjednik, 14. 10. 1993., 13.

90 L. BUTURAC 2002: 29.

91 ANGELIS 2011: 102-103.
} 
podrumima i tavanima sve dok nadbiskup Stepinac nije intervenirao kod ustaškog ministra Andrije Artukovića. ${ }^{92}$

Buturac ipak nije bio potpuno iskren kada je kasnije govorio i pisao o svojem djelovanju tijekom ustaškoga režima. Prešutio je niz rečenica u tekstovima $\mathrm{Ka}$ toličkog lista kojima je iskazivao svoju naklonost prema ustaškim vlastima i Anti Paveliću. Nisu izostali ni antikomunistički, protusrpski i antisemitski te izrazito nacionalistički stavovi. U tekstu „Teška iskušenja u našoj prošlosti ${ }^{\text {‘93 }}$ Buturac se potpisao pseudonimom Uskok ${ }^{94}$, a između ostaloga, napisao je: „Svećenički rad na vjerskom i moralnom preporodu hrvatskoga naroda ostaje i dalje jedan od vrlo

92 Isto: 103. Josip Buturac morao se 1943. skrivati od ustaša, kao što sam gore naveo, zbog teksta o naturalizaciji i kolonizaciji, a državni cenzor Ivo Bogdan smatrao je da se tekst odnosi na talijanske okupatore. O ovoj situaciji vidi u HR-DASB-PŽ-290, Osobni fond Josipa Buturca 1921. - 1995., kutija 2., Autobiografski materijal, Josip Buturac, Moja zapamćenja (rukopis), Lovrečina Grad, 1983., 57, 115; Isto, Josip Buturac, Zabilježbe - autobiografija Josipa Buturca po sjećanju i savjesti (rukopis), 105; Isto, kutija 4., Josip Buturac, Moja zapamćenja (rukopis pisan pisaćim strojem), I. dio, 9., 59., III. dio, 10; Isto, kutija 4., Josip Buturac, ,,Katolički list “ i Ivo Bogdan 1943. (rukopis pisan pisaćim strojem); J. BUTURAC 1994: 183, 204.

\section{BUTURAC 2002: 49.}

94 Josip Buturac koristio se pseudonimom Uskok i prije 1941. godine (Isto: 46; DAMIŠ 1995: 305, 306). Buturčevi tekstovi ustaške orijentacije potpisani pseudonimom Uskok, a objavljeni u Katoličkom listu 1941. godine, navedeni su u bibliografiji Josipa Buturca koju je sastavio Lojzo Buturac (L. BUTURAC 2002: 49), ali su izostavljeni u bibliografiji Josipa Buturca koju je pripremio Ivan Damiš. Zašto? Možda zato da ne bi kompromitirali Josipa Buturca. Petar Macut smatra da je autor spornih tekstova objavljenih pod pseudonimom Uskok Janko Penić jer je bio sklon ustašama, a Damiš sporne tekstove nije uvrstio u Buturčevu bibliografiju (MACUT 2016: 212-213). Zašto bi Buturac dopustio Peniću da se koristi njegovim pseudonimom? Osim toga, Damiš je stavio na popis Buturčevih radova tekst „Naše Međimurje“ koji je Buturac potpisao pseudonimom Uskok. Taj je tekst objavljen u Katoličkom listu 1941., a prije i nakon toga $u$ istoj godini izašla su po dva sporna teksta ustaške orijentacije iz Uskokova pera koje je, prema mišljenju Petra Macuta, vjerojatno napisao Janko Penić. Prvi od spornih tekstova „Teška iskušenja u našoj prošlosti“ izašao je u br. 31, a drugi „S nadom u bolju budućnost“ u br. 32. Ubrzo nakon toga, u br. 33 objavljen je tekst „Naše Međimurje“ koji je nedvojbeno napisao Josip Buturac, a potpisao ga je pseudonimom Uskok (L. BUTURAC 2002: 49; DAMIŠ 1995: 306). U br. 34 objavljen je treći sporni tekst potpisan pseudonimom Uskok pod naslovom „Uzgajanje naroda“, a u br. 35 i četvrti sporni tekst pod pseudonimom Uskok „Vjerski i narodni preporod sela“. Ovaj kontinuitet uočio je i Petar Macut. Zašto bi se Penić i Buturac izmjenjivali u korištenju istim pseudonimom? Petar Macut napisao je: „Napominjem da Josip Buturac u svojim člancima koje je napisao u vrijeme NDH nigdje nije nekritično hvalio ustaše ili poglavnika, odnosno njihovu politiku, kako je to slučaj s kanonikom Penićem..." (MACUT 2016: 213). Osim tekstova ustaške orijentacije potpisanih pseudonimom Uskok, postoje još najmanje dva teksta iz Buturčeva pera koji nedvojbeno pokazuju autorovu naklonost prema ustašama i poglavniku. Riječ je o tekstovima „Naseljavanje srednje Slavonije u prošlosti“ (Katolički list, 9. 4. 1942.) i „Naše patnje. Prigodom treće godišnjice obnovljene Hrvatske Države“ (Katolički list, 6. 4. 1944.), koje sam analizirao u ovom radu. Petar Macut je na kraju svoje analize napisao: „Vjerujem da je Penić napisao četiri prijeporna teksta koristeći se Buturčevim pseudonimom, iako dopuštam u svjetlu budućih istraživanja da se ovaj slučaj rasvijetli i na drugačiji način“" (MACUT 2016: 213). 
važnih rodoljubnih poslova. U tome radu neće svećenik više nailaziti na zapreke framazuna i marksista nego na potporu hrvatske državne vlasti.“95

Autor je i teksta „S nadom u bolju budućnost“996 objavljenog 14. kolovoza 1941. godine. Riječ je o tekstu izrazite ustaške orijentacije. Između ostaloga, naveo je: „Nezavisna Država Hrvatska stvorena je Božjom milošću, mudrim i požrtvovnim radom Poglavnika i ustaškog pokreta te voljom naših saveznika. Od osnutka Države do danas prošlo je kratko vrijeme od četiri mjeseca. Kroz to vrijeme učinjena su djela koja zadivljuju..." Nekoliko rečenica dalje nastavio je u istom tonu: „Odlučna volja Poglavnika, Njegovih suradnika i ustaškog pokreta daje nam jamstvo, da će se započetim putem ići odvažno dalje. Rad, red i poštenje jesu načela koja je ustaška vlada postavila sebi i cijeloj Hrvatskoj... Hrvatski je ustaški pokret oduvijek kod praktičnih katolika u Hrvatskoj dobro gledan i primljen. To je i sasvim razumljivo. Ono, što je svakoga zadivilo i privlačilo, jest iskrena ustaška domovinska ljubav... I upravo iz te i tako shvaćene ljubavi izrasla je i digla se odlučna ustaška borba za zapadnu kršćansku civilizaciju protiv sebičnjaka framazuna i zavodnika komunista te protiv svih naših narodnih neprijatelja.“ U istom je tonu nastavio: „Židovsko-komunističko-velikosrpska promičba u Hrvatskoj udarila je u prvom redu na crkvu i svećenike... ${ }^{697} \mathrm{U}$ tekstu „Uzgajanje naroda“ ${ }^{“ 98}$ Buturac (Uskok) je naveo: „Sada je i naopakosti u uzgajanju došao kraj. Nezavisna Država Hrvatska ići će u pogledu uzgajanja zdravim i sigurnim putem te ustaškom odlučnošću ukloniti sve prepreke. To se vidi iz različitih odredaba i djela hrvatske vlade, a još će se više vidjeti u budućnosti.“ Smatrao je da samo sporazum između Crkve i države glede odgoja može „ukloniti ono zlo u koje je ljudstvo zapalo poradi lažne demokracije i liberalizma“. Naveo je da „država ima spriječiti svaku komunističku, novovjersku i starovjersku promičbu koja katoličkoj Crkvu donosi štetu“. ${ }^{99} \mathrm{U}$ tekstu objavljenom 4. rujna 1941. godine pod naslovom „Vjerski i narodni preporod sela“ ${ }^{\text {“100 }}$ napisao je ${ }^{101}$ : „Nema više kulturne borbe za hrvatsko selo. Nezavisna Država Hrvatska uklonila je ju-

95 J. BUTURAC 1941a: 361-362.

96 L. BUTURAC 2002: 49.

97 J. BUTURAC 1941b: naslovna, 370.

98 L. BUTURAC 2002: 49.

99 J. BUTURAC 1941c: naslovna, 394-395.

100 L. BUTURAC 2002: 49.

101 U ovom je tekstu Uskok (Josip Buturac) spomenuo i svoj zavičaj: „Krasna zemlja oko sela Kule (kod Požege) 'nije mogla' prehraniti sve svoje hrvatske stanovnike, koji su zato preselili u Bekteže, ali je ta ista zemlja, u rukama Niemaca, učinila Kulu najbogatijim selom u Požeškoj kotlini.“ Uskok (Josip Buturac) nije zaboravio ni svoje rodno selo: „U Grabarju su pojedine zadruge s 10 do 20 jutara tako 'osiromašile', te nisu 'mogle' plaćati poreza, pa su zbog toga na porezu izgubile polovicu ili svu zemlju." I ovo je pokazatelj da se iza pseudonima Uskok krio Josip Buturac, a ne kanonik Janko Penić. 
goslavence, 'slobodarce' i komuniste te opet omogućila složan i uporedan rad za vjerski i narodni preporod hrvatskog sela." Uspjeh toga rada uvjetovan je, prema Uskokovu mišljenju, uklanjanjem sa sela posljedica „,slobodarsko-komunističkog djelovanja“. ${ }^{102}$ Tekst objavljen 9. travnja 1942. godine, potpisan prvim slovom imena i punim prezimenom (J. Buturac), pod naslovom „Naseljavanje srednje Slavonije u prošlosti“ završio je rečenicama: „Hvala Svevišnjemu Bogu, što nam je dao Poglavnika, i što smo preko ustaškog pokreta došli do ljudi, koji znadu, što treba učiniti za jačanje i čuvanje hrvatstva; i koji imaju smjelosti i snage, da postavljenu zadaću uistinu i izvedu. Ustaški će pokret popraviti pogreške prošlosti i učiniti srednju Slavoniju u moralnom, gospodarskom i svakom drugom pogledu snažnim dijelom velike, ustaške Hrvatske. " ${ }^{103}$ Izrazito proustaški, protupartizanski i antikomunistički tekst „Naše patnje. Prigodom treće godišnjice obnovljene Hrvatske Države“ izašao je 6. travnja 1944. godine na stranicama Katoličkog lista. Ponovno je objavljen u knjizi Znaci vremena (1994.), ali je uklonjen dio u kojem je autor otvoreno veličao Antu Pavelića i ustaše: „Ustaški pokret sa svojim vođom Poglavnikom razvio je zastave i prihvatio nametnutu borbu za hrvatsko ime i slobodu hrvatskoga naroda. Dana 10. travnja 1941. proglašena je Nezavisna Država Hrvatska i tako završeno prvo razdoblje ustaške borbe... "104 Nemoguće je da 1944. godine autor tih rečenica nije znao za genocidnu politiku ustaškoga režima prema Srbima, Romima i Židovima te za teror masovnih razmjera nad Hrvatima antifašističke orijentacije. O navedenim tekstovima ne samo da je šutio nego je kasnije i gradio sliku o sebi isključivo kao o protivniku ustaškog režima. Ipak, treba spomenuti da je Buturac i nakon političkih promjena početkom devedesetih godina zauzeo negativan stav prema ustaškom režimu i Anti Paveliću te osudio ustaške progone Srba, Roma, Židova i komunista, o čemu je već bilo riječi, a to je važno jer su ti stavovi iskazani tijekom rata u Hrvatskoj, kada to više nije bilo suviše poželjno.

Josip Buturac bio je protivnik četničkog pokreta, a ni prema partizanima nije pokazivao naklonost, naprotiv. Neke njegove stavove koji se odnose na Drugi svjetski rat nije moguće obraniti argumentima. U svojoj knjizi Znaci vremena, točnije, u već spomenutom tekstu „Naše patnje“, Buturac je, između ostaloga, napisao: „Četnička misao da treba iskorijeniti Hrvate kao narod prodahnula je sve partizane Srbe“. ${ }^{105}$ Možda je donekle u pravu kada je riječ o pojedinačnim slučajevima i grupama, ali da je četnička misao „prodahnula“ sve partizane Srbe, onda bi se mnogi od njih priključili četnicima, a ne partizanima. Ovo je

\footnotetext{
102 J. BUTURAC 1941d: naslovna.

103 ISTI 1942: 174.

104 ISTI 1944: naslovna.

105 ISTI 1994: 170.
} 
moguće uzeti u obzir kada je riječ o četnicima koji su prešli u partizane, a i u toj skupini postojali su razni motivi za priključenje Narodnooslobodilačkoj vojsci i partizanskim odredima. Dakako, ovo ne znači da u redovima partizana nije bilo srpskih ekstremista, ali Buturac je to naveo kao dominantnu pojavu, štoviše, sve Srbe partizane označio je kao one koji žele iskorijeniti Hrvate. U istom tekstu obrušio se i na komunizam. Napisao je da „Hrvati nisu tako slijepi da ne bi vidjeli kako pobjeda komunizma znači njihovo posvemašnje uništenje.“106 Nekoliko rečenica dalje stoje riječi: „Pobjeda komunizma u svijetu, kada bi je Bog privremeno dopustio, ne bi značila ni uništenje Crkve ni pobjedu bezboštva, nego najtežu kaznu upravo za one koji su svojim nemarom, sebičnošću i bezbožnošću pomogli širenje bezbožnoga komunizma. “ ${ }^{107}$ Buturac je vrlo kompleksnu ideologiju komunizma uglavnom reducirao na jedan aspekt odnosa komunista prema vjeri.

U tekstu „Moja sjećanja na nadbiskupa Alojzija Stepinca“, objavljenom u knjizi Znaci vremena, napisao je: ,sudjelovanje Hrvata partizana u ratu za oslobođenje od okupatora kao da nije imalo vrijednosti“ jer „su se Srbi četnici ponašali kao pobjednici, zauzeli su važne službe i vlast..." ${ }^{108}$ Koliko je Srba četnika zauzelo važne službe i vlast nakon Drugoga svjetskog rata u odnosu na Hrvate koji su prešli iz domobrana u partizane? Buturac je zanemario da je i dio pripadnika oružanih snaga NDH prešao u partizane. U svome tekstu „Cijela istina o odnosima četnici - komunisti“, objavljenom u Glasu koncila 8. prosinca 1991. pod pseudonimom Historicus, ${ }^{109}$ napisao je: „Hrvati komunisti su manjina i šutljivci koji nesvjesno pomažu četnike i velikosrpsku politiku. To se jasno očituje poslije 1945.g. Srbi su pobjednici, Hrvati poraženi, ne samo ustaše nego i komunisti. Srbi su povlašteni u Hrvatskoj, a Hrvati općenito progonjeni, pa i komunisti. Današnja stvarnost najbolje sve to potvrđuje..." ${ }^{\text {"110 }}$ Riječ je o tekstu napisanom i objavljenom u Buturčevoj dubokoj starosti, a uslijed rata u Hrvatskoj dodatno je zaoštrio svoje stavove o Srbima i dotaknuo granicu nacionalnog šovinizma. Slične stavove o komunistima i četnicima izložio je i u tekstu „Zašto nije ustanovljena istina o ratnim žrtvama?“. Osudio je ustaške zločine te spomenuo „velike patnje i za hrvatske i za srpske obitelji...", ali i napisao niz spornih i neutemeljenih podataka. Tvrdio je da su Srbi četnici izvršili genocid nad Hrvatima nakon Drugog

\footnotetext{
106 Isto: $171-172$.

107 Isto: 172.

108 Isto: 183

109 Poznavateljima specifičnoga stila pisanja i načina razmišljanja Josipa Buturca jasno je tko je autor niza tekstova objavljenih pod pseudonimom Historicus u Glasu koncila i jednoga u Službenom vjesniku Nadbiskupije zagrebačke tijekom 1991. i 1992. godine. Lojzo Buturac i Ivan Damiš naveli su te tekstove u Buturčevoj bibliografiji (L. BUTURAC 2002: 85-87, 88; DAMIŠ 1995: 317-318).

110 Glas koncila, 8. 12. 1991., 2.
} 
svjetskog rata. Ustašama je zamjerio što nisu ostvarili „,sporazum s komunistima Hrvatima o zajedničkoj obrani domovine..."111

O svome odnosu prema Srbima Buturac je zapisao: „Moji su odnosi prema Srbima bili uvijek korektni. Ni ja ni moji rođaci nisu nikome Srbinu učinili ništa nažao. Imao sam više Srba dobrih znanaca. U sukobu sam bio jedino s čaglićkim učiteljem Oblakovićem zbog njegova šovinizma i čaglićkim žandarima koji su me klevetali." Svoj korektan odnos prema Srbima potkrijepio je slučajem dječaka Veselka Zlojutra, koji je „1942. doveden s Kozare i predan u Čagliću katolkinji Anki Marošević na prehranu. Imao je 4 g. života. Starije od njega bile su njegove sestre Gospava i Bosiljka koje su u čaglićkim katoličkim kućama pomagale u kućnim poslovima. Majka mu je umrla u ratu, a otac otišao u njemačko zarobljeništvo. Kad se vratio iz rata, oženio se drugi puta i poručio djeci, pa tako i Veselku, neka ostane ondje gdje se nalazi jer se ne može za njega brinuti. To je izjavio i kod suda, pa je tako Anka uzela Veselka sebi za posinka. To nije sudski provedeno.“ Buturac je u nastavku teksta naveo da je dječak ,pohađao katolički vjeronauk, obavio prvu ispovijed i pričest, polazio nedjeljnu misu u Lipiku, učiteljica mu je u školskoj svjedodžbi napisala da je Hrvat. Nitko tome nije prigovarao iako se znalo da potječe od srpskih pravoslavnih roditelja..." Josip Buturac pomagao je Zlojutru tijekom školovanja, a neko je vrijeme kao student i stanovao kod njega. Kada je kasnije gradio kuću u Lipiku, Buturac mu je dao 600000 dinara. ${ }^{112}$ Budući da dječak u dobi od četiri godine nije mogao imati svijest o srpskom nacionalnom identitetu, a kasnije mu je barem formalno određen hrvatski identitet, ovaj slučaj ne govori mnogo o Buturčevu odnosu prema Srbima.

Sudeći prema njegovim pisanim radovima, Srbi su uglavnom spomenuti u negativnom kontekstu. Takvi su tekstovi posebno zastupljeni u trećem dijelu njegovih zapisa Moja zapamćenja. ${ }^{113} \mathrm{U}$ tekstu „Vjerska svijest kod pravoslavnih Srba“ Buturac je, između ostaloga, zapisao: „Nijemci su tiskali srpski crkveni zakonik po kome se vidi da je Srpska pravoslavna Crkva dobro organizirana. Međutim, nitko se nije potanje zabavio duhovnošću Srba pravoslavaca. Spominje se dogmatika i liturgija koje čuvaju staru kršćansku tradiciju. Moralno shvaćanje ljudskog života vrlo je daleko od kršćanstva. Poziva se na mržnju i osvetu, hvali se krađa i podvala. Laž je osobito uporna. Grijeh se ne priznaje. Kajanja nema. Ugovori se ne poštuju. Prijevara se preporuča i pohvaljuje. Srpski narod ima svoju posebnu ćud, narav, temperament s dobrim i lošim svojstvima na svoju i tuđu štetu. To nisu znali Strossmayer, Starčević, Radić, Meštrović, Kljaković i

\footnotetext{
$\overline{111}$ Glas koncila, 12. 1. 1992., 2.

112 HR-DASB-PŽ-290, Osobni fond Josipa Buturca 1921. - 1995., kutija 4., Josip Buturac, Moja zapamćenja (rukopis pisan pisaćim strojem), III. dio, 11 .

113 Isto, 34, 35, 40, 43, 46, 55.
} 
dr. Htjeli su pomoću jednoga 'đavla' (Srbi) tjerati drugoga 'đavla' (Mađari), pa smo dobili ono što imamo. “114 Ova razmišljanja prožeta dubokim predrasudama njihova pisca pokazuju da je sâm pisac, između ostaloga, bio slab poznavatelj duhovnosti i moralnih vrednota u okviru Srpske pravoslavne Crkve. ${ }^{115}$ Ako je Buturac imao u vidu isključivo lošu praksu, onda je to trebalo posebno naglasiti, ali i tada takvo razmišljanje o Srpskoj pravoslavnoj Crkvi i Srbima te Mađarima upućuje na zaključak da je nedvojbeno riječ o predrasudama, odnosno oblikovanju stava na temelju iskrivljenih shvaćanja problema pod snažnim utjecajem emocija, bez racionalne analize $\mathrm{i}$ argumenata.

U svome tekstu „Suživot Hrvata i Srba u Hrvatskoj domovini“, objavljenom pod pseudonimom Historicus, naveo je suživot između Hrvata i Srba kao životnu nužnost, ali je Srbe vidio kao gotovo jedine krivce za narušavanje odnosa s Hrvatima tijekom prošlosti. Nije uočavao promjene u kontekstu odnosa Hrvata i Srba. Smatrao je da su Srbi gosti i došljaci koji su „bježeći pred Turcima našli utočište u Hrvatskoj..." Prema njegovu mišljenju, Srbi se moraju prilagoditi „Zakonima i običajima nove domovine. “" ${ }^{116}$ Buturac je iz perspektive sadašnjosti (tadašnjosti) tumačio prošlost u rasponu od doseljavanja Srba na područje današnje Hrvatske do 1991. godine. „Da razumijemo svoje sadašnje teško stanje, treba se sjetiti povijesnih zbivanja i događaja, “"177 napisao je Historicus. U tekstu ,Zašto se zgražamo?" tendenciozno je postavio problem odnosa Hrvata i Srba, inzistirajući na kontinuitetu nasilja Srba prema Hrvatima od njihova doseljavanja na područje današnje Hrvatske pa sve do posljednjega rata, ali i nasilja kao modela za kojim su razne srpske političke grupe posezale u ostvarivanju svojih ciljeva (ubojstva Karađorđa, kralja Aleksandra Obrenovića itd.). ${ }^{118}$ Radi zaokružene i što cjelovitije slike o Buturčevu odnosu prema Srbima, treba spomenuti i njegovo sjećanje na jednoga suca: „Pomagao mi je sreski sudac u Pakracu Ilić, sin pravoslavnog paroha u Gospiću. Završio je život za rata u Jasenovcu što mi je veoma žao..."119 Ovaj navod proizlazi isključivo iz Buturčeva osobnog iskustva s pojedincem koji mu je učinio nešto dobro.

\footnotetext{
114 Isto, 55.

115 U tekstu „Zašto se zgražamo?“ Josip Buturac je teško optužio pravoslavno svećenstvo riječima: „Narodna ili državna crkva nije kršćanska. Ne možemo odbaciti ekumenizam, ali ni gajiti nekakvih nada u našim krajevima, kad i sami pravoslavni vjernici osuđuju svoje svećenike zbog šovinizma“"(Glas koncila, 5. 1. 1992., 2). Smatram da je ovdje evidentan šovinizam autora ovih rečenica.

116 Službeni vjesnik Nadbiskupije zagrebačke, 1991., br. 4, 123.

117 Isto.

118 Glas koncila, 5. 1. 1992., 2.

119 HR-DASB-PŽ-290, Osobni fond Josipa Buturca 1921. - 1995., kutija 2., Autobiografski materijal, Josip Buturac, Moja zapamćenja (rukopis), Lovrečina Grad, 1983., 111.
} 


\section{Stavovi o povijesnim ličnostima i suvremenicima}

Josip Buturac bio je hrvatski nacionalist i čovjek konzervativnoga svjetonazora prožetoga katoličkim pogledom na svijet, nesklon nekim ideološkim sustavima koji su obilježili europsku povijest dvadesetoga stoljeća, a posebno komunizmu i liberalizmu. Ponekad je i djelovanje pojedinih povijesnih ličnosti vrednovao s obzirom na njihov odnos prema Crkvi. Tako je za Antu Starčevića rekao: „On je govorio da su svećenici poživinčili hrvatski narod i da služe Austriji, neprijateljici. Katolička štampa ga je zvala antikristom. Majka mu je bila Srpkinja, pa je zbog toga imao tu lošu koncepciju..." ${ }^{120}$ Nekoliko rečenica prije ovoga naveo je: „Ante Starčević je pogriješio u tome što je smatrao da u Hrvatskoj žive pravoslavni Hrvati, a ne Srbi. Griješio je u tome što je smatrao da su bosanski muslimani dobri Hrvati... Na tim je zabludama on stvarao Veliku Hrvatsku." ${ }^{\text {"121 }}$ Međutim, Josip Buturac je ranije tvrdio da su „bosanski Hrvati muslimanske vjere ratovali hrabro na turskoj strani protiv katolika Hrvata, Madžara..."122 Taj zapis objavljen je 8. kolovoza 1941. godine u Katoličkom listu, točnije, u već spomenutom Uskokovu tekstu „Teška iskušenja u našoj prošlosti“. Dakle, i Buturac je, barem neko vrijeme, bosansko muslimansko stanovništvo smatrao Hrvatima. Ante Starčević živio je u periodu kada proces konstituiranja hrvatske nacije nije završen pa se njegovi stavovi mogu u određenoj mjeri razumjeti uzevši u obzir vrijeme u kojem su nastali. Međutim, Buturčev stav o hrvatskom identitetu bosanskih muslimana moguće je promatrati uglavnom u okvirima ustaške politike njihova uključivanja u hrvatski nacionalni korpus.

Stjepanu Radiću zamjerio je izjavu da „svaka duša ima ravan put u nebo, na tome putu ne treba popovskih mešetara“. ${ }^{123} \mathrm{Za}$ Stjepana Radića je, između ostaloga, rekao da „odbacuje Crkvu, odbacuje sakramente. On je kršćanin, a i nije kršćanin. Liberalac!“. ${ }^{124}$ Prema vlastitom priznanju u rukopisu Moja zapamćenja, Buturac je kao mladić uvjeravao seljake da je Radić demagog te je, između ostaloga, spomenuo da je svoje protivnike u Skupštini „,nazivao najpogrdnijim imenima (vucibatine, pljačkaši) i tako dao povoda Crnogorcu Puniši Račiću..., da usred Skupštine puca..."125 Dakle, negativni Buturčevi stavovi o Stjepanu Radiću uglavnom su utemeljeni na Radićevu odnosu prema svećenstvu i Crkvi. Na identičan način ocrtao je u negativnim bojama i Antu Starčevića. Rekao je da

120 ANGELIS 2011: 104-105.

121 Isto: 104.

122 J. BUTURAC 1941a: 360.

123 ANGELIS 2011: 105.

124 Isto.

125 HR-DASB-PŽ-290, Osobni fond Josipa Buturca 1921. - 1995., kutija 4., Josip Buturac, Moja zapamćenja (rukopis pisan pisaćim strojem), II. dio, 11. 
su liberali ,tuđi Crkvi. Devedeset posto naše inteligencije su liberalci, to znači od Crkve daleko, to znači da ne žele nikakve vjerske dužnosti. " 126 Ta je izjava uglavnom proizvoljna i nije utemeljena na relevantnim podacima, ali jasno ukazuje na njegov stav o nespojivosti liberalnih vrijednosti i nauka Katoličke Crkve.

Buturčeve konstatacije o jugoslavenskom kralju Aleksandru I. Karađorđeviću naivne su i simplificirane. U svojim zapisima tvrdi da su „državom vladale četničke organizacije koje je kralj tolerirao ili nije mogao protiv njih ništa učiniti: prije njega Srbi su ubili tri svoja vladara, pa je trebalo vladaru mnogo mudrosti da sačuva život.“ Buturac smatra da su diktaturu „skrivili i narodni zastupnici koji su se upravo natjecali u svađama, uvredama i podvalama, lažima, kao da su u cirkusu, da bi gledaoce i slušatelje zabavili i primili pljesak odobravanja. U tome su skoro jednaki: Hrvatski sabor prije 1918. i beogradska skupština poslije 1918.“ U nastavku istoga teksta navodi: „Smatralo se da je kralj Aleksandar objektivno kriv za progone Hrvata, Muslimana, Albanaca, Makedonaca i dr. Ipak su smrt njegovu žalili i Hrvati, a pobožne žene molile su za njegovu dušu krunicu. Svi su se bojali unutrašnjih nemira, ubijanja od strane četnika..."Budući da je kralj Aleksandar bio protivnik liberalizma i antikomunist te zagovornik konzervativnih vrijednosti, uzevši u obzir Buturčev odnos prema navedenim ideologijama, onda je njegov relativno povoljniji stav prema kralju Aleksandru u odnosu na Antu Starčevića i Stjepana Radića sasvim razumljiv. Buturac je očito smatrao da su Hrvati prihvatili kralja Aleksandra kao vladara jer su ,... smrt njegovu žalili...“127

Zanimljiv je i Buturčev komentar vezan uz položaj Katoličke Crkve u Kraljevini Jugoslaviji: „Iako je Katolička Crkva bila progonjena, zapostavljana i prikraćivana, treba i to priznati: država je biskupima davala plaću, siromašnim svećenicima doplatak na skupoću, plaćala je katehete i sjemeništa, brinula se za popravak crkvi, u vojsci se javno molio Očenaš, prije Diktature tisak je bio slobodan, hrvatska se zastava svuda vijala. “128 $\mathrm{Na}$ temelju svega što je naveo teško bismo mogli zaključiti da je „Katolička Crkva bila proganjana, zapostavljena i prikraćivana...“

Buturac je zabilježio i jednu situaciju iz 1934. godine koja u značajnoj mjeri pokazuje njegov odnos prema Austro-Ugarskoj i Jugoslaviji: „Za svoga boravka u Zavodu sv. Jeronima nadbiskup Šarić spominjao je pred svećenicima studentima da je saznao u Rimskoj kuriji kako se radi o (na, op. V. T.) osnutku katoličke podunavske države u koju bi ušle Austrija, Madžarska, Slovačka, Slovenija, Bavarska pa i Hrvatska. Dok su drugi svećenici šutjeli, ja sam se usudio reći nadbiskupu Šariću: Nije nikako razborito da katolički crkveni prelat prenosi iz Rimske kurije glasove o osnivanju nekakve katoličke podunavske države, što

126 ANGELIS 2011: 105.

127 HR-DASB-PŽ-290, Osobni fond Josipa Buturca 1921. - 1995., kutija 4., Josip Buturac, Moja zapamćenja (rukopis pisan pisaćim strojem), II. dio, 16.

128 Isto. 
znači odvajanje Hrvatske od Jugoslavije. Širenje takvih glasina može se shvatiti kao veleizdaja, i još $\mathrm{k}$ tome u vezi s Crkvom. Hrvati doduše nisu zadovoljni s velikosrpskom politikom u Jugoslaviji, ali ne mogu željeti da se vrate u državu s centrom u Beču koja im je ubila Zrinskog i Frankopana i ponašala se prema Hrvatskoj kroz 400 godina kao najgora maćeha." ${ }^{129}$ Tada je Jugoslavija za njega ipak bila ponešto manje zlo u odnosu na Austro-Ugarsku. Kasnije je ublažio svoj stav o Austro-Ugarskoj riječima: „Austrija je bila naša maćeha, ne majka, ali mi, njena pastorčad smo trebali čuvati tu majku. “130

Ante Pavelić je, prema sudu Josipa Buturca, iskazanom godinama nakon sloma ustaškog režima, negativna povijesna ličnost zbog progona Srba, Roma i Židova i komunista. ${ }^{131}$ Istaknuo je kako je Pavelić provodio „besmislene i štetne vjerske prelaze, progonio nevine i tako skrivio tešku osvetu i stradanje hrvatskoga naroda. “132 U trećem dijelu rukopisa Moja zapamćenja Buturac je Josipu Brozu Titu stavljao na teret stradanje Hrvata nakon Drugoga svjetskog rata. ${ }^{133}$ U razgovoru s Arisom Angelisom 1993. godine i u knjizi Znaci vremena, koja je objavljena nakon Buturčeve smrti, nije spomenuo Titovu odgovornost za stradanje Hrvata nakon Drugoga svjetskog rata. Prema Buturčevu mišljenju, Tito je propustio osigurati bolju zaštitu nacionalnih interesa hrvatskog naroda u Jugoslaviji. ${ }^{134}$ Istaknuo je da nije ,čuo od nadbiskupa Stepinca da bi Tito tražio od njega prekid s Rimskom stolicom“ ${ }^{\prime 135}$ te je dodao da se odvajanje Crkve u Jugoslaviji „u to doba priželjkivalo u Beogradu, što je ponešto utjecalo i na Tita“. ${ }^{136}$ Nekoliko rečenica prije toga naveo je Titovu izjavu ,da poštuje vjersku slobodu, pa i vezu s Rimom““. ${ }^{137}$ U istom tekstu citirao je izjavu koju je Tito navodno dao američkim novinarima: „Pustio bih Stepinca iz zatvora, ali Srbi ne daju“ ${ }^{138}$ Možda je Buturac imao u vidu Titov razgovor s dopisnikom New York Timesa, 6. studenog 1950. godine. U spomenutom razgovoru maršal Tito je, između ostaloga, rekao „da bi se pravoslavno stanovništvo pokazalo nezadovoljnim, kad bi Stepinac bio pušten na slobodu te kad bi otputovao u inozemstvo..." ${ }^{139}$ Prema mišljenju Josipa Buturca, „Stepinčeva

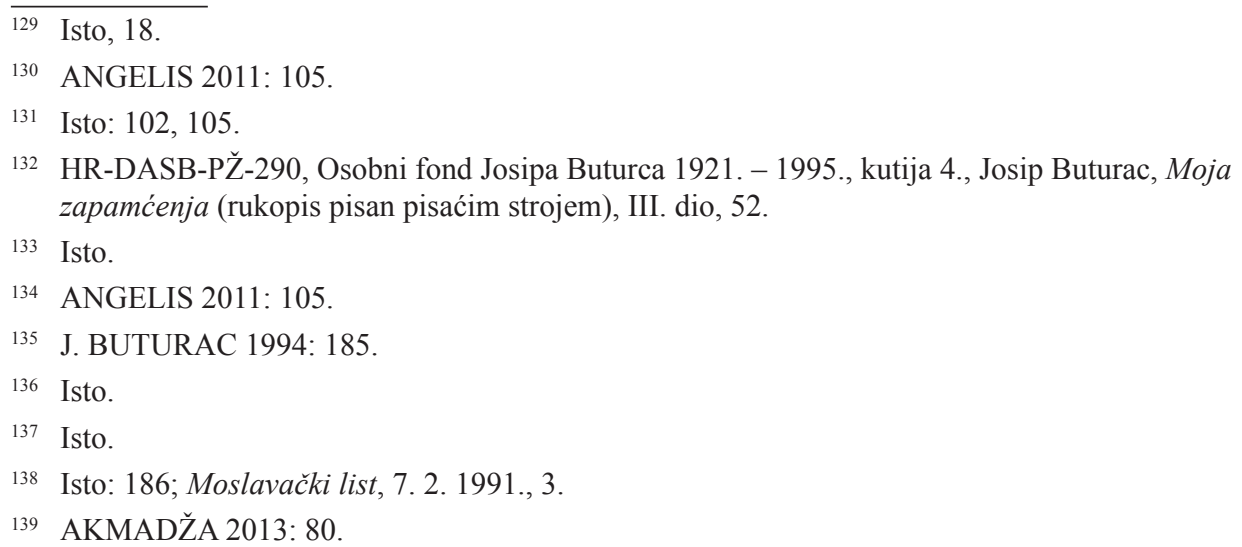


osuda uklapa se u opći plan o stvaranju Velike Srbije i uništenju hrvatskog naroda“. ${ }^{140}$ Ova rečenica jasno prikazuje koliko je Josip Buturac političke procese, ali i Srbe promatrao s pozicije njihove, prema Buturčevu uglavnom ideologiziranom razumijevanju, usmjerenosti protiv Hrvata.

Katolički vjerski i hrvatski nacionalni identitet, uz oslonac na crkvene autoritete, predstavljali su okvire u kojima je Josip Buturac živio i radio. To se ogleda i u njegovu stavu prema svećeniku Krunoslavu Draganoviću ${ }^{141}$ s kojim se družio tijekom studija u Rimu. Krunoslav Draganović studirao je na Orijentalnom institutu. Buturac je u svojim sjećanjima zabilježio da je od njega ,dosta toga naučio.“142 Detaljnije o svome odnosu s Draganovićem pisao je u trećem dijelu zapisa Moja zapamćenja. Pažljivom analizom toga teksta jasno je da Buturac daje za pravo onima koji su o Draganoviću pisali kao o hrvatskom dobrotvoru i „besprijekorno poštenom čovjeku“, a nije uzimao u obzir mišljenja njegovih kritičara. Čak je Danicu nazvao glasilom ,prokomunističkih katoličkih svećenika“ u kojem je netko navodno zatražio Draganovićevu smrt. Naveo je da se Draganović slobodno kretao nakon povratka u Jugoslaviju 1967. godine te da je radio kao profesor u Sarajevu i uređivao Opći šematizam Katoličke Crkve. Zapisao je kako je Draganovića pratila milicija te da su mu u jednom trenutku prijetili, a u drugom ga ostavljali na miru. Dvojica starih znanaca, Buturac i Draganović, susreli su se više puta nakon Draganovićeva povratka u socijalističku Jugoslaviju. ${ }^{143}$ Prema ovom kontroverznom rimokatoličkom svećeniku imao je stav neupitne naklonosti pa je, prema tome, Buturčevo mišljenje o njemu upitne vrijednosti.

Kada govorimo o ličnostima koje su bili njegovi uzori, u prvom redu treba spomenuti zagrebačkoga nadbiskupa Alojzija Stepinca, za koga je rekao da je ,iz njegovih jednostavnih riječi izlazilo nešto što je ne samo tješilo i hrabrilo nego i oduševljavalo“. ${ }^{144}$ Prema njegovu navodu, Stepinac mu se obratio riječima: „Oče Joso, budi mi prijatelj! Ja prijatelja nemam. Možeš li shvatiti kako je strašno kad jedan nadbiskup nema prijatelja. Ta i ja sam čovjek od krvi i mesa. I ja imam

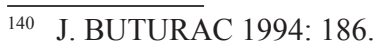

${ }^{141}$ Krunoslav Draganović bio je hrvatski povjesničar i rimokatolički svećenik te profesor na Rimokatoličkom bogoslovskom fakultetu u Zagrebu do 1943. godine. Od tada je radio u hrvatskom predstavništvu pri Svetoj Stolici. Nakon Drugog svjetskog rata pomagao je hrvatskim emigrantima u Italiji i Austriji. Omogućio je mnogim dužnosnicima ustaškog režima bijeg u države Južne Amerike. Detaljnije o djelovanju Krunoslava Draganovića u Tko je tko u NDH. Hrvatska 1941.-1945. 1997., s. v. „Draganović Krunoslav“, 96-98; AKMADŽA 2010.

142 HR-DASB-PŽ-290, Osobni fond Josipa Buturca 1921. - 1995., kutija 2., Autobiografski materijal, Josip Buturac, Moja zapamćenja (rukopis), Lovrečina Grad, 1983., 47.

143 Isto, kutija 4., Josip Buturac, Moja zapamćenja (rukopis pisan pisaćim strojem), III. dio, 28.

144 J. BUTURAC 1994: 188; Detaljnije o Alojziju Stepincu u HR-DASB-PŽ-290, Osobni fond Josipa Buturca 1921. - 1995., kutija 4., Josip Buturac, Moja zapamćenja (rukopis pisan pisaćim strojem), I. dio, 7-10, III. dio, 56. 
potrebu nekome se potužiti i povjeriti..." 145 Ako je taj navod u potpunosti točan, zasigurno upućuje na povjerljiv odnos Alojzija Stepinca prema Josipu Buturcu. Zato njegove navode i razmišljanja o zagrebačkom nadbiskupu treba ozbiljno razmotriti jer je Buturac očito bio upućen u neke aspekte Stepinčeva djelovanja.

Buturac se divio Alojziju Stepincu, a zagovarao je i njegovu beatifikaciju. ${ }^{146} \mathrm{U}$ spomenutom razgovoru s Arisom Angelisom prisjetio se svojih susreta s Alojzijem Stepincem: „Bio sam svaki dan s njime. Svaki razgovor s njime kao da je nešto zračilo iz njega, poslije razgovora osjećao sam se jačim“. ${ }^{147}$ Tijekom rata morao je u Katoličkom listu ispuštati dijelove Stepinčevih govora „čuvajući tako njegovu i svoju glavu od smrti“. Zapisao je i riječi koje mu je navodno rekao sâm Alojzije Stepinac nakon prvog uhićenja, o pitanju odgovornosti za pisanje katoličkog tiska u doba ustaškog režima. Naime, Stepinac je rekao da je preuzeo odgovornost za pisanje katoličkoga tiska, iako nije intervenirao, nego je dopustio autorima da slobodno pišu i objavljuju svoje tekstove. To je učinio kako bi drugima olakšao položaj. ${ }^{148}$ Sudeći po tome, Alojzije Stepinac bio je svjestan da su neki autori katoličkog tiska pisali tekstove $u$ funkciji ustaške propagande te je imao predodžbu o njihovoj odgovornosti iz perspektive nove vlasti uspostavljene 1945. godine. ${ }^{149}$

Analizirajući i vrednujući rad vodećih ličnosti moderne i suvremene hrvatske povijesti, Josip Buturac svoje je stavove uglavnom oblikovao prema njihovu odnosu spram Katoličke Crkve i kršćanskih vrijednosti te u nešto manjoj mjeri hrvatskog nacionalnog pitanja. Vrlo rijetko osvrtao se na problem građanskih sloboda i socijalnih prava u djelovanju političara o kojima je govorio i pisao. Treba naglasiti da su djela u kojima su prikazana Buturčeva razmišljanja o vodećim hrvatskim povijesnim ličnostima autobiografskog i publicističkog, a ne historiografskog karaktera pa si je dopustio slobodniji pristup.

\section{Razmišljanja o braku i svakodnevna stremljenja}

Buturac je posvećivao pozornost tradicionalnim vrijednostima, a posebno pitanju obitelji i braka: „... Gledam oženjenu braću i sestre. Svi se oni jako tuže. Najprije, ne slažu se muž i žena, onda briga za djecu, pogotovo ako djeca nisu dobra. Razmišljao sam o tome u kojem staležu čovjek ima više slobode, u svećeničkom ili oženjenom. I konačno sam došao do toga da su u oženjenom staležu roditelji

\footnotetext{
145 HR-DASB-PŽ-290, Osobni fond Josipa Buturca 1921. - 1995., kutija 4., Josip Buturac, Moja zapamćenja (rukopis pisan pisaćim strojem), I. dio, 8.

146 ANGELIS 2011: 103-104.

147 Isto: 104.

148 HR-DASB-PŽ-290, Osobni fond Josipa Buturca 1921. - 1995., kutija 4., Josip Buturac, Moja zapamćenja (rukopis pisan pisaćim strojem), I. dio, 9-10; J. BUTURAC 1994: 185.

149 Detaljnije o katoličkom tisku u NDH u MACUT 2016.
} 
robovi djece, zatim sloboda bračnih partnera ograničena je jer se moraju prilagoditi pogreškama svog bračnog druga, inače će se razići. A svećenik je slobodan u svakom pogledu, svakako više nego onaj u oženjenom staležu..." ${ }^{150}$ Smatra da se većina „mora ženiti i udavati jer je to Božja volja. "151 O mješovitim brakovima rekao je da „nikada nisu dosta stalni ni sređeni, jer da dvoje žive zajedno, moraju se složiti u mnogim stvarima. Ako se radi o vjeri, to je onda i kultura i puno toga. Ako su oni tu različiti, nema takve časovite ljubavi koja ih može trajno vezati. Tako da se ti mješoviti brakovi prije ili kasnije razilaze..." 152 Dakle, smatrao je da je vjerski identitet bračnih drugova važniji od same ljubavi jer ako partneri ne pripadaju istoj vjeri, brak je osuđen na propast. I na tom primjeru vidljiva je njegova suzdržanost prema drugačijima te mogućnostima da pripadnici različitih vjerskih zajednica ostvare uspješan i dugotrajan brak. U svom tekstu „Mješovite ženidbe“, objavljenom u Katoličkom listu 1935. godine, između ostaloga, napisao je: „Kazaće nam da nismo tolerantni. Pa neka nam kažu! Mi znamo da u vjeri, vjerskim stvarima pa i ženidbi ne može biti tolerancije. Tko bi tu bio tolerantan, taj bi bio kukavica jer bi se odricao svoje vjere..."153

Tijekom svoga svećeničkog života Josip Buturac ulagao je velik napor u postizanje raznih vrlina. Njegov duhovni razvoj, razmišljanja i dileme, odluke i ciljeve moguće je pratiti u Bilježnici iz duhovnog života koju je marljivo pisao. Zapisivao je odluke poput: „1. Čitanje dobrih knjiga iz beletristike 2. Bilježenje lijepih figura i riječi 3. Valjano spremanje za propovijed 4. Govor s više vedrine i oduševljenja 5. Zanimati se za tuđi život 6. Ne govoriti o sebi 7. Paziti da se drugi ne uvrijedi 8. Ne ogovarati 9. Govoriti dobrim književnim jezikom 10. Govoriti krepko, točno i odlučno 11. Govoriti s ljubavlju i iskreno". Postavio si je visoke duhovne ciljeve i u tom smislu odlučio da će ostati posve ravnodušnim kada ga „drugi omalovažavaju i preziru“ te da nikoga neće „ogovarati, omalovažavati, osuđivati i prezirati“, a izbjegavat će „kino i slične zabave“. Smatra da mora „pokazivati veselje zbog tuđe sreće“, a da ne smije „nikada nikome zavidjeti“ i da će „tražiti svugdje nešto lijepo“. Promišljao je o ljepoti i odlučio „uzgajati cvijeće“, „oduševljavati djecu za ljepotu“, ,u ljepoti gledati veličinu Božju“, „,biti zadovoljan s onim što imam“. Mnoge njegove rečenice sadrže misli o čovjeku i njegovim dvojbama: „Samo onaj koji je nezavisan, može da ispuni mjesto u borbi života.“ Bilo mu je važno „,biti taktičan i prilagoditi se drugima“ te „vedar, veseo, uslužan, pouzdan“. Istaknuo je da „čovjek vedre duše može puno podnijeti“ te da „,dobro srce i vesela ćud donosi uspjeh“. Drži da je velik dar „biti dobre volje

\footnotetext{
AN0 ANGELIS 2011: 106-107.

151 Isto: 107.

152 Isto: 95.

153 J. BUTURAC 1935b: 485.
} 
i slagati se s ljudima koji neprestano grde i lako se uzrujavaju“. Nemarnost je smatrao zločinom, a cijenio je samopouzdanje, sabranost, blagost, plemenitost i pobožnost. Buturčeva Bilježnica iz duhovnog života otkriva njegova najintimnija promišljanja o plemenitim nastojanjima čovjeka svjesnog svoje grešnosti koja mu je zadavala čestu unutrašnju borbu. ${ }^{154}$

Nije bilježio koliko je imao uspjeha u nastojanju da svojim životom ostvari temeljne kršćanske vrline. Po svemu sudeći, nije bio svjestan svojih predrasuda prema drugima, a posebno prema pravoslavnim Srbima, komunistima i liberalima. S druge strane, osudio je ustaške progone Srba, Židova, Roma i komunista, iako je u doba tih progona i sâm iskazivao naklonost tom režimu. Teško je reći je li u iskazivanju naklonosti ustaškom režimu bio potpuno iskren ili je možda u određenoj mjeri riječ o oportunizmu kojega u takvim vremenima nikada nije nedostajalo. Smatram da ne treba isključiti niti strah za vlastitu sigurnost jer ljudi u strahu pružaju otpor ili se identificiraju s izvorom straha.

U autobiografskim rukopisima te u knjizi Znaci vremena imao je potrebu pisati o nevoljama s ljudima poput učitelja Tanasija Oblakovića ${ }^{155}$ i svećenika Dragutina Kniewalda ${ }^{156}$ koji ga je navodno ,prozvao koljačem. ${ }^{\text {“157 }} \mathrm{O}$ toj neugodnoj situaciji s Kniewaldom nastavlja: „To je bila teška i opasna optužba, a posve bez temelja. Ipak mi nisu naškodile te neosnovane optužbe zbog moje suradnje u 'Katoličkom listu' za vrijeme rata." ${ }^{158}$ Navodio je i benignije situacije pa u svojim sjećanjima nije zaboravio ni Franju Šepera: „Godine 1943. rektor sjemeništa dr. F. Šeper otkazao mi je hranu u sjemeništu, ali ne i dr. Peniću, uredniku, ni svećenicima Švigiru i Stehnu. "159

Bio je izložen borbi koju ponekad nije nametnuo, ali nije se pokoravao ako je bio uvjeren u ispravnost ciljeva te borbe. $U$ navedenim autobiografskim zapisima možemo čitati o stvarnim i/ili navodnim nevoljama koje su ga zahvatile u Kraljevini Jugoslaviji, u NDH tijekom Drugog svjetskog rata i u socijalističkoj Jugoslaviji nakon rata, a te su nevolje, prema njegovim opisima, uvijek drugi uzrokovali, često ljudi iz njegove neposredne blizine, pa i pojedini crkveni dostojanstvenici. Treba naglasiti da se Buturac dobro integrirao u socijalističkom sustavu. Poštovao je konvencije i uvažavao formu. Znao se prilagoditi prilikama u kojima se našao,

\footnotetext{
$\overline{154}$ HR-DASB-PŽ-290, Osobni fond Josipa Buturca 1921. - 1995., kutija 3., Josip Buturac, Bilježnica iz duhovnog života (rukopis).

155 Isto, kutija 4., Josip Buturac, Moja zapamćenja (rukopis pisan pisaćim strojem), I. dio, 57; J. BUTURAC 1994: 199.

156 HR-DASB-PŽ-290, Osobni fond Josipa Buturca 1921. - 1995., kutija 4., Josip Buturac, Moja zapamćenja (rukopis pisan pisaćim strojem), I. dio, 18; J. BUTURAC 1994: 208.

157 J. BUTURAC 1994: 205.

158 Isto.

159 Isto: 204
} 
ali kao svećenik bio je dosljedan i nerijetko isključiv u svjetonazoru te marljiv i uporan u gotovo svemu što je radio.

\section{Drugi o Buturcu}

Poznati povjesničar Đorđe Stanković problematizirao je djelatnost Josipa Buturca. U svojoj knjizi Izazov nove istorije (2) iz 1994. Stanković je, uz ostalo, napisao: „Uostalom, do koje mere je ovaj katolički pisac, po duhu i obrazovanju jezuita a po političkom ubeđenju 'pravaš' i 'ustaški djelatnik', kao istoriograf falsifikator (sledbenik Krunoslava Draganovića), dovoljno pokazuje upravo slučaj ubistva 'grčkog vladike Evrema'. Opširnija ekspozicija je nužna jer je upravo dr. Josip Buturac svojim brojnim delima znatno uticao na izgrađivanje istorijske svesti katolika 'Zlatne doline', a kao posleratni (od 1945.) dugogodišnji 'arhivistički upravitelj' i poznavalac arhiva Zagrebačke nadbiskupije u Državnom arhivu Hrvatske, i na istorijsku i na uopšte društvenu svest Hrvata. Kada u svojoj knjizi Katolička crkva u Slavoniji za turskog vladanja (Zagreb, 1970.) govori o feudalnim vlastelinstvima u Slavoniji u XV i početkom XVI veka, pre dolaska Turaka, Buturac ne kaže da su to bili mađarski i nemački posedi, već čitalac stiče utisak da je to 'hrvatska baština'. I to kakva!“‘160

Smatram da je Đorđe Stanković uglavnom reducirao djelovanje Josipa Buturca samo na neke, i to selektivno izdvojene aspekte. Buturca možemo smatrati ustaškim djelatnikom tijekom Drugog svjetskog rata, ali držim spornim pri tome zanemarivati njegov rad prije 1941. i nakon 1945. godine. Osim toga, autor citiranih rečenica nije posegnuo za nizom argumenata koje mu je sâm Buturac stavio na raspolaganje u više svojih tekstova objavljenih u doba NDH. Buturac je nedvojbeno bio hrvatski nacionalist, ali Đorđe Stanković nije iznio relevantne argumente kojima bi dokazao da je Buturac bio pravaš. Autor je zanemario kompleksnost hrvatskog nacionalizma. Nisu svi hrvatski nacionalisti pravaši. Buturčeva naklonost prema Draganoviću te njegova suradnja s njim ipak nije čvrst dokaz Stankovićeve tvrdnje da je bio njegov sljedbenik. Trebao je precizno pojasniti svoj stav. Je li Buturac bio krivotvoritelj? Nedvojbeno je često promatrao prošlost iz perspektive svoje sadašnjosti, jednodimenzionalno, ideologizirano, zanemarujući kontekst, ali ne bih se usudio složiti s Đorđem Stankovićem u njegovoj ocjeni. Buturčev prikaz ubojstva vladike Evrema ${ }^{161}$ ipak nije dovoljan argument za Stankovićeve tvrdnje o Buturcu, ali ih nije moguće niti zanemariti.

160 STANKOVIĆ 1994: 14-19.

161 Vladika Evrem ubijen je u Kuli nedaleko od Požege 1639. godine. Ubili su ga rimokatolici jer je od njih skupljao prihode. O tom događaju pisao je i Josip Buturac (BUTURAC 1970: 193196). Nisam shvatio kako je Đorđu Stankoviću opis toga događaja iz Buturčeva pera poslužio kao dokaz za njegove tvrdnje o Buturcu. 
Povodom smrti Josipa Buturca Tomislav Radonić napisao je u Požeškom listu: „Njegovom smrću Požeština, požeška i hrvatska historiografija, i arhivska djelatnost izgubili su plodnog i istaknutog znanstvenog djelatnika“. ${ }^{162}$ Spomenuti tekst svjedoči da je Josip Buturac do kraja mislio na požeški zavičaj. Naime, prema Radonićevim riječima, Buturac je nekoliko dana prije smrti poslao „Društvu za hrvatsku povjesnicu i Povijesnom arhivu u Požegi svoje zadnje pismo upućeno u rodni kraj. U njemu dr. Buturac s nestrpljenjem očekuje izlazak iz tiska svoje knjige Spomenici Požege i okolice I dio. Upućuje nas u svoj depozit u Arhivu Hrvatske koji sadrži mikrofilmove iz Rima u svezi Požege, ukazuje nam na obvezu prikupljanja turskih dokumenata“ ${ }^{163}$ Ugledni požeški novinar Ivan Jakovina je, komentirajući Buturčev odlazak, napisao: „I u trenutku kada se bitno mijenja odnos prema njemu i njegovom djelu u pozitivnom smislu, preminuo je radeći i stvarajući poletno i mladenački, bez obzira na duboku starost, doslovno do zadnjeg daha." ${ }^{164}$

Poznati požeški neuropsihijatar Savo Treskanica prisjetio se susreta s Buturcem: „Bio je susretljiv i ugodan u komunikaciji s vrlo istančanim smislom za šalu. Stekao sam utisak da je "punim plućima' sudjelovao u životu. "165 Te su riječi uglavnom potvrdili i dugogodišnji župnik Župe svetoga Leopolda Bogdana Mandića u Požegi, Vjekoslav Marić, te povjesničar i publicist Tomislav Radonić. ${ }^{166}$ Marić je dodao da je Buturac vrlo otvoreno drugima iskazivao primjedbe, ali bio je i spreman saslušati te razmotriti one koje su drugi njemu upućivali. ${ }^{167}$ Miodrag Bjelić, umirovljeni pukovnik JNA, jedan od organizatora partizanskog ustanka 1941. u požeškom kraju te poznati požeški publicist, u dvama navratima istaknuo je da poštuje Buturčev historiografski rad, ali, prema njegovu mišljenju, Buturčev odnos prema neistomišljenicima ponekad je prelazio granice prihvatljivoga. ${ }^{168}$ Jedan od Buturčevih najvećih protivnika, učitelj Tanasije Oblaković, prema navodu Ivice Miškulina, u veljači 1933. godine, o Buturcu je, između ostaloga, naveo: ,... On na svakom koraku sipa otrov protiv svega što nije čisto katoličko i što nema veze s Rimom i Svetom stolicom. Verski fanatik i zanešenjak, večito je u nekoj verskoj ekstazi i egzaltiranosti. Jedan u svakom pogledu nemoguć i nepristupačan čovek." ${ }^{169}$ Čitajući navedene Buturčeve tekstove u Katoličkom listu od 1941. do 1944. godine te nekoliko analiziranih u ovom radu, ali i drugih

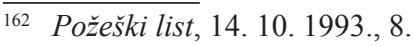

163 Isto.

164 Isto.

165 Savo Treskanica, razgovor s autorom, Požega, 9. svibnja 2015.

166 Vjekoslav Marić, razgovor s autorom, Požega, 11. svibnja 2015; Tomislav Radonić, razgovor s autorom, Požega, 12. svibnja 2015.

167 Vjekoslav Marić, razgovor s autorom, Požega, 5. 6. 2018.

168 Miodrag Bjelić, pukovnik JNA i publicist, razgovor s autorom, Zagreb, 14. 7. i 20. 12. 2013.

169 MIŠKULIN 2010: 87, 102.
} 
tekstova objavljenih u Glasu koncila početkom devedesetih godina, smatram da mogu sasvim utemeljeno reći da je uistinu ,sipao otrov" prema drugima, a u Glasu koncila ponajprije prema Srbima. Navedene izjave o Buturcu upućuju na složenost njegove ličnosti. Njegov rad nije moguće odrediti jednoznačnim stavovima.

\section{Zaključak}

Ideologija, osobna uvjerenja, emocije, životna iskustva, predrasude, vjerska i nacionalna pripadnost često su u značajnoj mjeri određivali Buturčeve stavove o prošlosti, posebno kada je riječ o modernoj i suvremenoj hrvatskoj povijesti. Ovo je jasno vidljivo na primjerima njegovih razmišljanja o vodećim ličnostima hrvatske povijesti druge polovine 19. i 20. stoljeća. Kategorije poput vjere, nacije i domovine imale su naglašenu ulogu u njegovu životu i mišljenju. Historicus je lavirao između kršćanskoga humanizma i radikalnog hrvatskog nacionalizma. Taj je problem posebno uočljiv kada je riječ o složenom odnosu prema Srbima i ustaškom režimu. Ipak, sudeći po pisanoj ostavštini, Buturac se brinuo o učincima svojih postupaka, a to je na poseban način uočljivo u njegovoj Bilježnici iz duhovnog života. Uzjaku nacionalnu i vjersku identifikaciju uvjetovanu potrebom za pripadanjem, u Buturca je evidentna i ljudska identifikacija koja je ponajprije proizlazila iz njegova kršćanskog svjetonazora, ali ne treba zaboraviti da „od ideološkog obilježavanja do nasilja, ima svega nekoliko koraka.“" ${ }^{170}$ Ipak, jaka nacionalna i vjerska, dakle grupna identifikacija, Buturca nije ometala u kreiranju njegova individualnog svijeta. ${ }^{171}$

Bio je nesklon liberalizmu i komunizmu, reduciravši ih gotovo isključivo na odnos njihovih zagovornika (liberala i komunista) prema Crkvi i vjeri. U tom odnosu primjećivao je samo jednu dimenziju, $i$ to onu koja nije bila po volji ovom konzervativnom svećeniku. S druge strane, Buturcu je, prema njegovim riječima, prigovorena navodna bliskost s komunistima nakon njihova dolaska na vlast. Za razliku od jednoga dijela svojih kolega svećenika, Buturac nakon dolaska komunista na vlast nije javno iskazivao svoje mišljenje o novom poretku. Prijelomne 1945. godine bio je javna ličnost i svećenik u državnoj službi te postoji visoka vjerojatnost da su nadležni organi komunističke vlasti provjerili njegovu djelatnost tijekom ustaškog režima, pogotovo nakon tvrdnje svećenika Dragutina Kniewalda da je Buturac poticao borbu protiv komunista. Narednih osam godina ostao je bez

$\overline{170}$ DUGANDŽIJA 2010: 73.

171 Nikola Dugandžija je u svojoj knjizi Nacionalna zbilja i njezini prividi, između ostaloga, napisao: „Grupna identifikacija nas oslobađa napora da se pojavljujemo i kao graditelji svojih malih individualnih svjetova.“ (Isto: 93) Ta konstatacija utemeljena je na brojnim primjerima, ali slučaj Josipa Buturca pokazuje da se pojedinac može istovremeno identificirati s grupom $i$ graditi svoj mali individualni svijet. Međutim, postavlja se pitanje kako će taj pojedinac reagirati ako pripadnost grupi dovede u pitanje njegov individualni svijet. Kako bi se u takvoj situaciji postavio Josip Buturac? 
službe na Rimokatoličkom bogoslovskom fakultetu, ali je i dalje radio ako arhivist u Državnom arhivu. Svojim radom i sposobnostima ostvario je uspješnu arhivističku i historiografsku karijeru. I sâm je napisao da mu Kniewaldove izjave nisu naštetile, iako je protiv sebe imao i tada relativno utjecajnog svećenika Svetozara Rittiga. Nadležnim je strukturama nove komunističke vlasti sasvim sigurno bio potreban manji napor, $u$ odnosu na mene i Petra Macuta, $u$ otkrivanju identiteta autora koji se koristio pseudonimom Uskok. Za razliku od jednog dijela svećenika, uključujući i zagrebačkog nadbiskupa Alojzija Stepinca, Buturac nije bio spreman uime antikomunističkih ideala dovesti u pitanje svoj status i profesionalnu karijeru javno ukazujući na grijehe političke elite i/ili je možda bio svjestan uzaludnosti, pa čak i mogućih kontraproduktivnih posljedica takvog djelovanja. Komunističke vlasti bile su uglavnom spremne osigurati prihvatljivo mjesto i za takve pojedince u novom sustavu. Riječ je o uglednom građaninu socijalističke Jugoslavije, iako nije pripadao skupini „prokomunističkih katoličkih svećenika“, kako je odredio svoje kolege okupljene oko Danice.

Ljudima koji su mu nanosili nepravdu nije lako opraštao. Bio je suurednik Katoličkog lista u vrijeme ustaškog režima, suradnik i dobar znanac Krunoslava Draganovića te u bliskom, gotovo prijateljskom odnosu s Alojzijem Stepincem. Nastavio je druženje s Krunoslavom Draganovićem nakon njegova povratka iz emigracije u socijalističku Jugoslaviju.

Zbog osjećaja prema zavičaju često je istraživao i pisao o problemima vezanim uz povijest požeškoga kraja. Svojim djelom uvrstio se u red najznačajnijih pisaca o prošlosti Požeške kotline, ali i cijele Slavonije.

Negov život i stvaralaštvo, a posebno arhivistički i historiografski rad predstavljaju opsežan i slojevit problem. Ovaj je rad uvid u njegovu kompleksnu biografiju i višeslojni identitet Josipa Buturca koji se svojim djelom pozicionirao u red značajnih povjesničara i publicista. Radi se o povjesničaru koji je prvi otvorio niz pitanja vezanih uz crkvenu i zavičajnu povijest, ponudio moguće odgovore i tako olakšao posao budućim znanstvenicima koji će nastaviti ondje gdje je on stao, ali i kritički valorizirati njegovo djelo. Problem koji je potrebno istražiti odnosi se na metodološki pristup Buturčevim historiografskim djelima. Trebalo bi usporediti metodološke aspekte njegovih historiografskih radova s djelima drugih povjesničara, njegovih suvremenika, te utvrditi sličnosti i razlike. Njegovo sudjelovanje u Hrvatskom katoličkom pokretu između dvaju svjetskih ratova ostaje nezaobilazno pitanje budućih istraživanja. Važno je spomenuti mogućnost proširivanja i produbljivanja analize kompleksnog odnosa Buturca i katoličkog svećenstva prema ustaškom režimu u širem kontekstu tadašnjih teških političkih prilika te poziciju Josipa Buturca i njegovih kolega tijekom složenog razdoblja socijalizma. Smatram važnim istražiti i problem kako su njegovi protivnici vidjeli svoje odnose s njim. Ovo su samo važnije u nizu istraživačkih mogućnosti koje se odnose na Josipa Buturca. 


\section{Bibliografija}

Arhivski izvori

AFSP - Arhiv franjevačkog samostana u Požegi, Ostavština Josipa Buturca.

HR-DASB-PŽ-290 - Državni arhiv u Slavonskom Brodu, Odjel u Požegi - 290, Osobni fond Josipa Buturca 1921. - 1995.

\section{Objavljeni izvori}

ANGELIS, Aris. 2011. Ljudi XX. stoljeća. Zagreb: Disput.

BUTURAC, Josip. 1970. Katolička crkva u Slavoniji za turskoga vladanja. Zagreb: Kršćanska sadašnjost.

BUTURAC, Josip. 1981. Božjakovina-Brckovljani 1209-1980. Iz povijesti župe, uprave i gospoštije. Brckovljani: Hrvatsko književno društvo sv. Ćirila i Metoda.

BUTURAC, Josip. 1982. Stubica Donja i Gornja 1209-1982. Iz povijesti obiju župa. Stubica - Zagreb: Kršćanska sadašnjost.

BUTURAC, Josip. 1990a. Župa Sveti Đurđ. Zagreb - Sveti Đurđ: Hrvatsko književno društvo sv. Ćirila i Metoda, Župa Sveti Đurđ.

BUTURAC, Josip. 1990b. Regesta za spomenike Požege i okolice 1221-1860. Zagreb: Hrvatsko književno društvo sv. Ćirila i Metoda.

BUTURAC, Josip. 1994. Znaci vremena. Rasprave iz hrvatske crkvene prošlosti (19321945). Zagreb: Matica hrvatska.

Zaključci Hrvatskog sabora, sv. I.-VII., 1958. - 1970.

\section{Periodika}

BUTURAC, Josip. 1932a. Starokatolici u Bijeloj Stijeni. Katolički list, 14. 1. 1932., 18-20.

BUTURAC, Josip. 1932b. Oko katehizacije u čagličkoj župi. Katolički list, 12. 5. 1932., 236-238.

BUTURAC, Josip. 1935a. Sjećanje na čaglićku župu. Katolički list, 19. 9. 1935., 472-474.

BUTURAC, Josip. 1935b. Mješovite ženidbe. Katolički list, 26. 9. 1935., 484-485.

BUTURAC, Josip. 1941a. Teška iskušenja u našoj prošlosti. Katolički list, 8. 8. 1941., 360-362. (Uskok)

BUTURAC, Josip. 1941b. S nadom u bolju budućnost. Katolički list, 14. 8. 1941., naslovna, 370. (Uskok)

BUTURAC, Josip. 1941c. Uzgajanje naroda. Katolički list, 28. 8. 1941., naslovna, 394395. (Uskok)

BUTURAC, Josip. 1941d. Vjerski i narodni preporod sela. Katolički list, 4. 9. 1941., naslovna, 406. (Uskok)

BUTURAC, Josip. 1942. Naseljavanje srednje Slavonije u prošlosti. Katolički list, 9. 4. 1942., 172-174. 
BUTURAC, Josip. 1944. Naše patnje. Prigodom treće godišnjice obnovljene Hrvatske Države. Katolički list, 6. 4. 1944., naslovna, 158-159.

BUTURAC, Josip. 1980. Rod Buturaca u Djedinoj Riki 1780-1980. Traženja - časopis za književnost, kulturu i društvena pitanja 22: 23-27.

Glas koncila, 8. 12. 1991., 2; 5. 1. 1992., 2; 12. 1. 1992., 2; 1. 8. 1993., 2.

Moslavački list, 7. 2. 1991., 3.

Požeški list, 29. 3. 1990., 5; 19. 4. 1990., 8; 26. 4. 1990., 1; 10. 5. 1990., 2; 14. 10. 1993., 8; 25. 2. 1993., 9.

Požeške novine, 13. 7. 1929., 3-4.

Sisački tjednik, 14. 10. 1993., 13.

Službeni vjesnik Nadbiskupije zagrebačke, 1991., br. 4, 123.

Veritas - revija svetoga Antuna Padovanskog, lipanj 1985., br. 6.

Razgovori

Miodrag Bjelić, pukovnik JNA i publicist, razgovor s autorom, Zagreb, 14. 7. i 20. 12. 2013.

Vjekoslav Marić, svećenik u miru, razgovor s autorom, Požega, 11. 5. 2015. i 5. 6. 2018.

Tomislav Radonić, povjesničar i publicist, razgovor s autorom, Požega, 12. 5. 2015.

Savo Treskanica, neuropsihijatar, razgovor s autorom, Požega, 9. 5. 2015.

\section{Literatura}

AKMADŽA, Miroslav. 2010. Krunoslav Draganović. Iskazi komunističkim istražiteljima. Zagreb - Slavonski Brod: Hrvatski institut za povijest, Podružnica za povijest Slavonije, Srijema i Baranje.

AKMADŽA, Miroslav. 2013. Katolička Crkva u komunističkoj Hrvatskoj 1945.-1980. Zagreb - Slavonski Brod: Hrvatski institut za povijest, Podružnica za povijest Slavonije, Srijema i Baranje.

BUTURAC, Lojzo. 1998. Josip Buturac u krugu obitelji i sela Djedine Rijeke. Zlatna dolina - Godišnjak Požeštine IV/1: 374-378.

BUTURAC, Lojzo. 2002. Život i djelo dr. Josipa Buturca. Jastrebarsko - Zagreb: Naklada Slap, Hrvatski državni arhiv.

DAMIŠ, Ivan. 1995. Dr. Josip Buturac, arhivist i povjesničar - biobibliografski podaci uz 80. rođendan. Zlatna dolina - Godišnjak Požeštine I/1: 293-320.

DUGANDŽIJA, Nikola. 2010. Nacionalna zbilja i njezini prividi. Zagreb: Durieux.

MACUT, Petar. 2016. U sjeni križa, samokresa i noža. Katolički tisak u Nezavisnoj Državi Hrvatskoj. Split: Redak.

MIŠKULIN, Ivica. 2010. Čaglićka epizoda - prilog životopisu Josipa Buturca. Croatica Christiana Periodica, XXXIV/66: 87-113.

NOSIĆ, Mato. 1998. Pogled na pjesnički rad dr. Josipa Buturca. Zlatna dolina-Godišnjak Požeštine IV/1: 379-387. 
PATAFTA, Daniel. 2017. Historiografska i arhivistička ostavština Josipa Buturca. Croatica Christiana Periodica, XLI/79: 159-174.

PAVLICA, Dane. 1979. Rad analfabetskih tečajeva u toku NOB-e na području Požeške kotline i Slavonije. Vjesnik Muzeja Požeške kotline 2-3: 211-233.

RADONIĆ, Tomislav. 1994. Čuvar hrvatske prošlosti. Požeški pučki kalendar: 72-73.

RADONIĆ, Tomislav. 2008. Život i djelo dr. Josipa Buturca (1905-1993.). Požega: Državni arhiv u Slavonskom Brodu - Odjel u Požegi.

STANKOVIĆ, Đorđe. 1994. Izazov nove istorije (2), Beograd: Vojna knjiga.

\section{Enciklopedije i leksikoni}

Hrvatska enciklopedija, sv. 2: Be - Da, s. v. „Buturac, Josip“. 2000. Zagreb: Leksikografski zavod Miroslav Krleža.

Hrvatski biografski leksikon, sv. 2: Bj - C, s. v. „Buturac, Josip“. 1989. Zagreb: Jugoslavenski leksikografski zavod Miroslav Krleža.

Hrvatski leksikon, sv. I: A - K, s. v. „Buturac, Josip“. 1996. Zagreb: Naklada Leksikon.

Opća enciklopedija Jugoslavenskog leksikografskog zavoda, sv. 1: A - Bzu, s. v. „Buturac, Josip“. 1977. Zagreb: Jugoslavenski leksikografski zavod Miroslav Krleža.

Požeški leksikon, s. v. „Buturac, Josip“. 1977. Slavonska Požega: Skupština općine Slavonska Požega.

Tko je tko u Hrvatskoj - Who is who in Croatia, s. v. „Buturac, Josip“. 1993. Zagreb: Golden marketing.

Tko je tko u NDH. Hrvatska 1941.-1945., s. v. „Draganović, Krunoslav“. 1997. Zagreb: Minerva. 


\section{Josip Buturac and his world}

This article deals with the life and work of a priest, publicist, historian and archivist Josip Buturac and is mainly based on the analysis of both his published and unpublished autobiographical works and other relevant sources of his personal collection kept in the Croatian State Archives in Slavonski Brod, Department of Požega. The objective of this article is to present and discuss Buturac's life and work as well as to analyse his attitude towards the main political ideas of the $19^{\text {th }}$ and $20^{\text {th }}$ centuries, assessment of activities of the main characters of modern and contemporary Croatian history, national and religious identity and his relationship with his native land, especially when it comes to his literary works which are greatly related to the history of the Požega Valley. In order to make his life and his world more transparent, this article explores Josip Buturac's attitude towards the Serbs, chetniks, partisans, Ustasha and his contemplation on his moral, intellectual, and spiritual endeavours and dilemmas. He was a man with the conservative outlook, an anti-communist and an adversary of liberalism. His life is intertwined with radical Croatian nationalism and Christian humanism, exclusiveness and tolerance, dialogue and conflict. But when it comes to his activity during the socialist regime, he shows highly adaptive skills which can be seen in his mostly successful integration in the Yugoslav socialist regime. His ideological prejudice and emotions sometimes made him construct distorted image of the past. His literary works represent a significant contribution to understanding of the history of the Catholic Church in Croatia and the development of archive systems.

Prijevod sažetka: Dolores Mataija

Keywords: conservatism, liberalism, communism, Chetniks, Partisan movement, Ustasha regime, archive systems, historiography, Catholic Church.

Ključne riječi: konzervativizam, liberalizam, komunizam, četnici, partizanski pokret, ustaški režim, arhivistika, historiografija, Katolička Crkva.

Vinko Tadić

Filozofski fakultet Sveučilišta u Zagrebu

Ivana Lučića 3, 10000 Zagreb

vinko.tadich@gmail.com 


\section{FILOZOFSKI FAKULTET SVEUČILIŠTA U ZAGREBU \\ ZAVOD ZA HRVATSKU POVIJEST \\ INSTITUTE OF CROATIAN HISTORY \\ INSTITUT FÜR KROATISCHE GESCHICHTE}

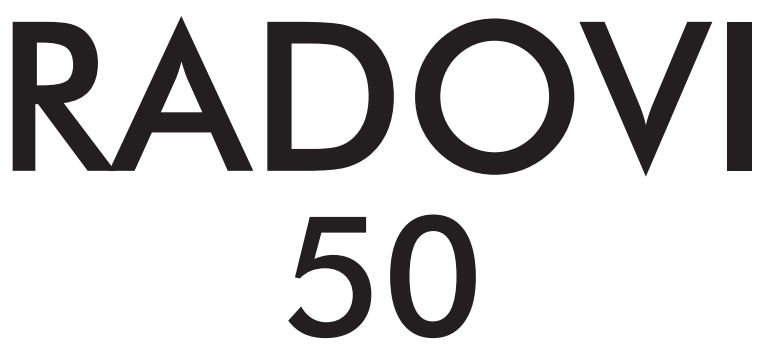

BROJ 2

ZAVOD ZA HRVATSKU POVIJEST

FILOZOFSKOGA FAKULTETA SVEUČILIŠTA U ZAGREBU

\section{FF press}

ZAGREB 2018. 


\title{
RADOVI ZAVODA ZA HRVATSKU POVIJEST FILOZOFSKOGA FAKULTETA SVEUČILIŠTA U ZAGREBU
}

\author{
Knjiga 50, broj 2
}

\author{
Izdavač / Publisher \\ Zavod za hrvatsku povijest \\ Filozofskoga fakulteta Sveučilišta u Zagrebu \\ FF-press \\ Za izdavača / For Publisher \\ Vesna Vlahović Štetić \\ Glavni urednik / Editor-in-Chief \\ Hrvoje Gračanin \\ Izvršni urednik / Executive Editor \\ Nikola Anušić \\ Uredništvo / Editorial Board
}

Bruna Kuntić-Makvić (stara povijest/ancient history), Zrinka Nikolić Jakus (srednji vijek/

medieval history), Hrvoje Petrić (rani novi vijek/early modern history), Željko Holjevac (moderna povijest/modern history), Tvrtko Jakovina (suvremena povijest/contemporary history),

Silvija Pisk (mikrohistorija i zavičajna povijest/microhistory and local history),

Zrinka Blažević (teorija i metodologija povijesti/theory and methodology of history)

Međunarodno uredničko vijeće / International Editorial Council

Denis Alimov (Sankt Peterburg), Živko Andrijašević (Nikšić), Csaba Békés (Budapest), Rajko Bratož (Ljubljana), Snježana Buzov (Columbus, Ohio), Svetlozar Eldarov (Sofija), Toni Filiposki

(Skopje), Aleksandar Fotić (Beograd), Vladan Gavrilović (Novi Sad), Alojz Ivanišević (Wien),

Egidio Ivetić (Padova), Husnija Kamberović (Sarajevo), Karl Kaser (Graz),

Irina Ognyanova (Sofija), Géza Pálffy (Budapest), Ioan-Aurel Pop (Cluj),

Nade Proeva (Skopje), Alexios Savvides (Kalamata), Vlada Stanković (Beograd),

Ludwig Steindorff (Kiel), Peter Štih (Ljubljana)

Izvršni urednik za tuzemnu i inozemnu razmjenu /

Executive Editor for Publications Exchange

Martin Previšić

Tajnik uredništva / Editorial Board Assistant

Dejan Zadro

Adresa uredništva/Editorial Board address

Zavod za hrvatsku povijest, Filozofski fakultet Zagreb, Ivana Lučića 3, HR-10 000, Zagreb

Tel. ++385 (0)1 6120 150, 6120 158, faks ++385 (0)1 6156879

Časopis izlazi jedanput godišnje / The Journal is published once a year

Časopis je u digitalnom obliku dostupan na / The Journal in digital form is accessible at

Portal znanstvenih časopisa Republike Hrvatske „Hrčak“ http://hrcak.srce.hr/radovi-zhp

Financijska potpora za tisak časopisa / The Journal is published with the support by Ministarstvo znanosti, obrazovanja i športa Republike Hrvatske

Časopis je indeksiran u sljedećim bazama / The Journal is indexed in the following databases: Directory of Open Access Journals, EBSCO, SCOPUS, ERIH PLUS, Emerging Sources Citation Index - Web of Science 


\title{
Naslovna stranica / Title page by
}

Iva Mandić

\section{Grafičko oblikovanje i računalni slog / Graphic design and layout Marko Maraković}

\author{
Lektura / Language editors \\ Samanta Paronić (hrvatski / Croatian) \\ Dražen Nemet (engleski / English)
}

Tisak / Printed by

Tiskara Zelina, Sv. Ivan Zelina

Naklada / Issued

200 primjeraka / 200 copies

Časopis je u digitalnom obliku dostupan na Portalu znanstvenih časopisa Republike Hrvatske „Hrčak“ http://hrcak.srce.hr/radovi-zhp

The Journal is accessible in digital form at the Hrcak - Portal of scientific journals of Croatia http://hrcak.srce.hr/radovi-zhp 